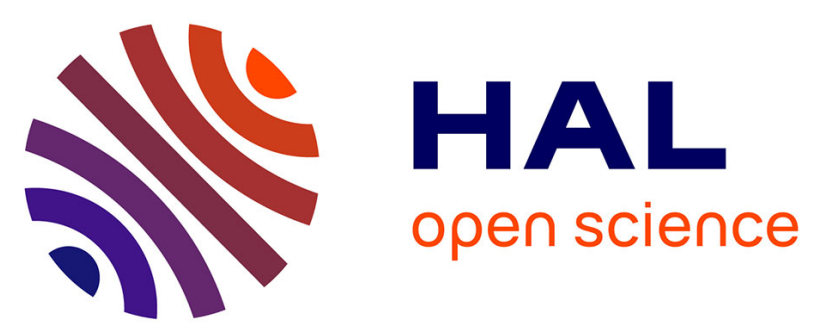

\title{
Interaction of Ddc1 and RPA with single-stranded/double-stranded DNA junctions in yeast whole cell extracts: Proteolytic degradation of the large subunit of replication protein $\mathrm{A}$ in $\operatorname{ddc} 1 \Delta$ strains
}

Maria V Sukhanova, Claudine d'Herin, Serge Boiteux, Olga I Lavrik

\section{To cite this version:}

Maria V Sukhanova, Claudine d'Herin, Serge Boiteux, Olga I Lavrik. Interaction of Ddc1 and RPA with single-stranded/double-stranded DNA junctions in yeast whole cell extracts: Proteolytic degradation of the large subunit of replication protein A in ddc1 $\Delta$ strains. DNA Repair, 2014, 22, pp.30-40. 10.1016/j.dnarep.2014.07.002 . hal-01180894

\author{
HAL Id: hal-01180894 \\ https://hal.science/hal-01180894
}

Submitted on 30 Jun 2021

HAL is a multi-disciplinary open access archive for the deposit and dissemination of scientific research documents, whether they are published or not. The documents may come from teaching and research institutions in France or abroad, or from public or private research centers.
L'archive ouverte pluridisciplinaire HAL, est destinée au dépôt et à la diffusion de documents scientifiques de niveau recherche, publiés ou non, émanant des établissements d'enseignement et de recherche français ou étrangers, des laboratoires publics ou privés. 


\title{
Interaction of Ddc1 and RPA with single-stranded/double-stranded DNA junctions in yeast whole cell extracts: Proteolytic degradation of the large subunit of replication protein $\mathrm{A}$ in $d d c 1 \Delta$ strains
}

\author{
Maria V. Sukhanova ${ }^{\mathrm{a}, \mathrm{b}}$, Claudine D’Herin $^{\mathrm{c}}$, Serge Boiteux ${ }^{\mathrm{c}, *}$, Olga I. Lavrik ${ }^{\mathrm{a}, \mathrm{b}, * *}$ \\ anstitute of Chemical Biology and Fundamental Medicine Siberian Division of the Russian Academy of Sciences, Prospect Lavrentieva 8, Novosibirsk 630090, \\ Russia \\ ${ }^{b}$ Novosibirsk State University, Novosibirsk 630090, Russia \\ ${ }^{\mathrm{c} C e n t r e ~ N a t i o n a l ~ d e ~ l a ~ R e c h e r c h e ~ S c i e n t i f i q u e, ~ U P R 4301, ~ C e n t r e ~ d e ~ B i o p h y s i q u e ~ M o l e ́ c u l a i r e, ~} 45071$ Orléans Cedex 02, France
}

\begin{abstract}
To characterize proteins that interact with single-stranded/double-stranded (ss/ds) DNA junctions in whole cell free extracts of Saccharomyces cerevisiae, we used $\left[{ }^{32} \mathrm{P}\right]$-labeled photoreactive partial DNA duplexes containing a 3'-ss/ds-junction (3'-junction) or a 5'-ss/ds-junction (5'-junction). Identification of labeled proteins was achieved by MALDI-TOF mass spectrometry peptide mass fingerprinting and genetic analysis. In wild-type extract, one of the components of the Ddc1-Rad17-Mec3 complex, Ddc1, was found to be preferentially photocrosslinked at a $3^{\prime}$-junction. On the other hand, RPAp70, the large subunit of the replication protein A (RPA), was the predominant crosslinking product at a $5^{\prime}$-junction. Interestingly, ddc1 $\Delta$ extracts did not display photocrosslinking of RPAp70 at a 5'-junction. The results show that RPAp70 crosslinked to DNA with a $5^{\prime}$-junction is subject to limited proteolysis in $d d c 1 \Delta$ extracts, whereas it is stable in $W T$, rad $17 \Delta$, mec $3 \Delta$ and mec $1 \Delta$ extracts. The degradation of the RPAp70-DNA adduct in ddc1 $\Delta$ extract is strongly reduced in the presence of the proteasome inhibitor MG 132 . We also addressed the question of the stability of free RPA, using anti-RPA antibodies. The results show that RPAp70 is also subject to proteolysis without photocrosslinking to DNA upon incubation in $d d c 1 \Delta$ extract. The data point to a novel property of Ddc1, modulating the turnover of DNA binding proteins such as RPAp70 by the proteasome.
\end{abstract}

\section{Introduction}

DNA damage can arise as a consequence of normal cellular metabolism and the action of exogenous genotoxic agents [1]. To maintain the genome integrity, eukaryotic cells have evolved sophisticated mechanisms, one of which is DNA damage checkpoint control [2,3]. DNA damage checkpoint provides monitoring of genome integrity during cell cycle, delaying or arresting cycle progression after detecting of DNA lesions [2-4]. Impaired DNA damage checkpoint response increases DNA damage sensitivity

\footnotetext{
* Corresponding author at: Centre National de la Recherche Scientifique, UPR4301, Centre de Biophysique Moléculaire, 45071 Orléans Cedex 02, France. Tel.: +33238257690.

** Corresponding author at: Institute of Chemical Biology and Fundamental Medicine Siberian Division of the Russian Academy of Sciences, Prospect Lavrentieva 8, Novosibirsk 630090, Russia. Tel.: +7 3833635195.

E-mail addresses: serge.boiteux@cnrs-orleans.fr (S. Boiteux), lavrik@niboch.nsc.ru (O.I. Lavrik).
}

in yeast and the risk of tumor development in humans [5,6]. The molecular mechanism of checkpoint control involves the action of three groups of proteins: sensors, signal transducers and effectors [2-4]. Sensor proteins act at the early steps of the checkpoint response that involves primary detection of DNA damage [2-4]. They recognize DNA repair/replication intermediates containing single-stranded DNA (ssDNA), double-stranded/singlestranded (ds/ss) DNA junctions, gaps or specific DNA-protein complexes such as ssDNA coated by replication protein A (RPA) $[7,8]$. Genetic and biochemical studies reveal that at least two complexes (Mec1-Ddc2) and (Ddc1-Rad17-Mec3), the (9-1-1) clamp in high eukaryotes, are involved in initial DNA damage recognition step in Saccharomyces cerevisiae [9,10]. These complexes independently localize at the sites of DNA damage $[9,10]$. Mec1-Ddc2 was shown to bind to ssDNA coated with RPA [11]. The (Ddc1-Rad17Mec3) complex is structurally related to PCNA and its recruitment to DNA damage in vivo depends on the Rad24- $\mathrm{RFC}_{2-5}$ clamp loader complex [12-15]. Biochemical studies have been carried out to determine DNA substrate specificity of the (9-1-1) complex in vitro 
[13-16]. It has been shown that the appropriate DNA substrates for loading of the (Ddc1-Rad17-Mec3) checkpoint clamp contain $3^{\prime}$ - or $5^{\prime}$-ss/ds DNA junctions, that are generated during doublestrand breaks repair, nucleotide excision repair (NER) or at stalled replication forks $[3,17-21]$. The efficiency and specificity of the (9-1-1) clamp loading can be modulated by RPA that directs $5^{\prime}-$ loading $[16,22,23]$. Therefore, the identification of proteins acting at ss/dsDNA junctions is critical to understand DNA damage response (DDR) in eukaryotes [24].

The aim of this study was to characterize proteins interacting with partial DNA duplexes containing $3^{\prime}$-ss/dsDNA or $5^{\prime}$-ss/dsDNA junctions in whole cell free extracts of $S$. cerevisiae using the photoaffinity labeling approach. Photoreactive DNA probes were generated by inserting a photoreactive analog of dCTP (FABGdCTP) at the margin of the ss/dsDNA junction. Photoactivation of such DNA probes results in photocrosslinking of proteins bound at ss/dsDNA junctions, which are identified by MALDI-TOF MS peptide mapping and genetic analysis [25]. Here, we found that the (9-1-1) checkpoint clamp component, Ddc1, was preferentially crosslinked to the $3^{\prime}$-junction DNA substrate. Interestingly, Ddc1 can interact with $3^{\prime}$-junction DNA in the absence of the two other checkpoint clamp partners, Rad17 or Mec3, under conditions when clamp cannot be formed. On the other hand, we found that RPAp70, the large subunit of RPA, is the predominant crosslinking product with the $5^{\prime}$-junction DNA substrate. Intriguingly, extracts deleted for Ddc1 did not display photocrosslinking of RPA with 5 '-ss/dsDNA substrate. The data show that RPAp70 crosslinked to DNA is rapidly cleaved in $d d c 1 \Delta$ extracts yielding limit products, whereas it is stable in $W T$, $\operatorname{rad} 17 \Delta, \operatorname{mec} 3 \Delta$ and mec $1 \Delta$ extracts. Furthermore, the degradation of RPAp70-DNA adducts in ddc1 $\Delta$ extract is reduced in the presence of the proteasome inhibitor MG 132. We also investigated the stability of RPA non-crosslinked to DNA using anti-RPA antibodies. The data show that RPAp70 is also subject to proteolysis without photocrosslinking to DNA upon incubation in ddc1 $\Delta$ extract, whereas it is stable in $W T$, rad17 $\Delta$ and $\mathrm{rad} 24 \Delta$ extracts. These results led us to propose that Ddc1 is likely involved in cellular processes, independently of the (9-1-1) checkpoint clamp structure, regulating proteasome-dependent degradation of DNA-binding proteins, like RPA.

\section{Materials and methods}

\subsection{Materials}

Synthetic oligonucleotides were obtained from "Eurogentec S.A." (Belgium) and Laboratory of Medical Chemistry (Institute of Chemical Biology and Fundamental Medicine (ICBFM), Novosibirsk, Russia). [ $\left.\gamma^{-32} \mathrm{P}\right]$ ATP, $\left[\alpha-{ }^{32} \mathrm{P}\right] \mathrm{dATP}(5000 \mathrm{Ci} / \mathrm{mmol}$ or $3000 \mathrm{Ci} / \mathrm{mmol}$ ) were from the Laboratory of Biotechnology (ICBFM, Novosibirsk, Russia) or "Perkin-Elmer", respectively. Protein molecular mass markers were from "Fermentas" and "BioRad". Protease inhibitors trans-epoxysuccinyl-L-leucylamido(4guanidino)butane (E-64), pepstatine A, o-phenanthroline monohydrate and 4-(2-aminoethyl)benzenesulfonyl fluoride hydrochloride (AEBSF) and proteasome inhibitor MG 132 were from "Sigma". A peptide calibration standard II was from "Bruker Daltonics" (Germany, Part No. 222570). Streptavidin MagneSphere Paramagnetic Particles, sequencing grade modified trypsin (porcine, part No. V5111), reagents for electrophoresis and basic components of buffers were from "Promega". ECL detection system was from "Thermo Scientific", hyperfilm-ECL was from "Amersham Biosciences". Horseradish peroxidaseconjugated goat anti-rabbit IgG were from "Invitrogen". The photoreactive dCTP analog, FABGdCTP (exo-N-[4-(4-azido-2,3,5,6,tetrafluorobenzylidenehydrazinocarbonyl)-butylcarbamoyl]2'-deoxycytidine-5'-triphosphate), was a kind gift from Dr.
Table 1

Saccharomyces cerevisiae strains used in this study.

\begin{tabular}{llll}
\hline Strain & Genotype & & Reference \\
\hline FF18733/34 & MATa/ $\alpha$ & $\begin{array}{l}\text { leu2-3,112, trp1-289, } \\
\text { his7-2 ura3-52, lys1-1 }\end{array}$ & {$[25]$} \\
AC91 & FF18734 & With rad17::KanMX6 & {$\left[\mathrm{lc}^{\mathrm{a}}\right]$} \\
BG49 & FF18734 & With ddc1::LEU2 & {$[\mathrm{lc}]$} \\
BG27 & FF18734 & With rad24::KanMX6 & {$[\mathrm{lc}]$} \\
BA055 & FF18733 & With mec3::LEU2 & {$[\mathrm{lc}]$} \\
AC53 & FF18733 & With mec1::KanMX6 & {$[\mathrm{lc}]$} \\
& & sml1::URA3 &
\end{tabular}

a lc: Our laboratory collection.

I.V. Safronov (ICBFM, Novosibirsk, Russia). The 5'-modified oligonucleotide with photoreactive exo-N-[4-(4-azido-2,3,5,6,tetrafluorobenzylidenehydrazinocarbonyl)-butylcarbamoyl group was synthesized by Dr. Silnikov V.N. (ICBFM, Novosibirsk, Russia).

\subsection{Proteins and cell extracts}

T4 polynucleotide kinase was from "Fermentas" (Canada) and "Biosan" (Russia). Rat DNA polymerase $\beta$ was overexpressed and purified as described [26]. Yeast RPA expression vector was a kind gift of M.S. Wold (University of Iowa, Iowa City, USA). Yeast RPA was overexpressed in Escherichia coli and purified as described [27]. Yeast Gst-Ddc1 was overexpressed in E. coli and purified as described [25]. Recombinant (Ddc1-Rad17-Mec3) complex was a kind gift of Peter M. Burgers (Department of Biochemistry and Molecular Biophysics, Washington University School of Medicine, St. Louis, USA). Rabbit polyclonal antibody against yeast RPA was a kind gift of X. Veaute (CEA, Fontenay aux Roses, France) and V. Gely (CNRS, Marseille, France). Rabbit polyclonal antibody against yeast Ogg1 was prepared as described [28]. Whole cell extracts from $W T$, ddc $1 \Delta, \operatorname{mec} 3 \Delta, \operatorname{rad} 17 \Delta$ and rad $24 \Delta$ yeast cells were prepared as described [25]. Protein concentration in extracts was $10-20 \mathrm{mg} / \mathrm{ml}$ determined by the Bradford assay.

\subsection{Yeast strains and microbiological methods}

S. cerevisiae strains used in this study are listed in Table 1 . Deletion mutant strains were constructed in the FF18733/34 wild-type $(W T)$ background. Deletions were obtained using PCR-based allele replacement techniques [29,30]. All disruptions were confirmed by PCR and genetic analysis. Cells were grown at $30^{\circ} \mathrm{C}$ in standard media YPD ( $1 \%$ yeast extract, $1 \%$ bacto-peptone, and $2 \%$ glucose).

\subsection{Preparation of photoreactive DNA substrates}

The nucleotide sequence and structure of the two oligodeoxyribonucleotides probes, DNA*1 and DNA*2, used in this study are shown (Table 2). To generate DNA*1, the upper primer was 5 -end-labeled using T4 polynucleotide kinase and $\left[\gamma^{-32} \mathrm{P}\right] \mathrm{ATP}$ (5000-6000 Ci $/ \mathrm{mmol}$ ), and the photoreactive dCTP analog (FABGdCTP) was incorporated by DNA polymerase $\beta$ (Pol $\beta$ ) into 3 '-end of the primer (Table 2$)$. Standard reaction mixtures $(300 \mu \mathrm{l})$ contained $50 \mathrm{mM}$ Tris- $\mathrm{HCl}, \mathrm{pH} 8.0,50 \mathrm{mM} \mathrm{NaCl}, 10 \mathrm{mM} \mathrm{MgCl}_{2}, 0.1 \mu \mathrm{M}$ Pol $\beta$ and $70 \mu \mathrm{M}$ FABGdCTP, $0.5 \mu \mathrm{M} 5^{\prime}$-[ $\left.{ }^{32} \mathrm{P}\right]$-labeled partial DNA duplex. The reaction mixtures were incubated for $15 \mathrm{~min}$ at $37^{\circ} \mathrm{C}$ to allow elongation of the primer with FABGdCMP, and then the reaction was stopped by adding EDTA to final concentration $20 \mathrm{mM}$ followed by precipitation by adding $1 / 10$ volume of $3 \mathrm{M} \mathrm{NaAc}, \mathrm{pH} 5.0$ and 2.5 volume of $96 \%$ ethanol. The photoreactive DNA*1 was dissolved in TE buffer to a final concentration $2 \mu \mathrm{M}$.

To generate $\mathrm{DNA}^{*} 2$, the upper primer carrying the photoreactive group (FABG) at the $5^{\prime}$-end was labeled by using $\left[\alpha-{ }^{32} \mathrm{P}\right] \mathrm{dATP}$ and Pol $\beta$. Standard reaction mixtures $(300 \mu \mathrm{l})$ containing $50 \mathrm{mM}$ 
Table 2

Nucleotide sequence and structure of DNA substrates.

\begin{tabular}{|c|c|}
\hline Nucleotide sequences and structures & Designation \\
\hline $\begin{array}{l}{ }^{\mathrm{a}} \mathrm{FABG} \\
1 \\
\left.5^{\prime}-\mathrm{-}^{32} \mathrm{p}\right]-\mathrm{GGCTTCATCGTTGTCCC} \\
3^{\prime}-\quad \text { CCGAAGTAGCAACAGGGTCTGGACCACCTATGGC-5' } \\
\text { or }(-5 \text { '-biotin })\end{array}$ & $\begin{array}{c}\text { DNA*1 } \\
\text { or } \\
\text { 3'-junction }\end{array}$ \\
\hline 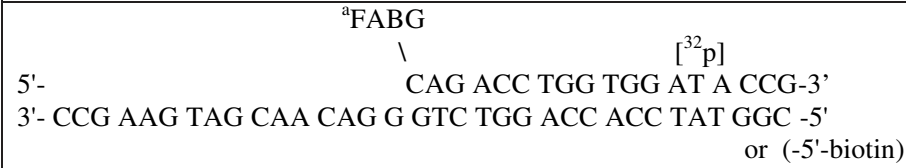 & $\begin{array}{c}\mathrm{DNA}^{* 2} \\
\text { or } \\
5 \text { '-junction }\end{array}$ \\
\hline
\end{tabular}

aFABGdCMP: exo-N-[4-(4-azido-2,3,5,6,-tetrafluorobenzylidenehydrazinocarbonyl)-butylcarbamoyl]-2'-deoxycytidine-5'-monophosphate; p - phosphate.

Tris- $\mathrm{HCl}, \mathrm{pH} 8.0,50 \mathrm{mM} \mathrm{NaCl}, 10 \mathrm{mM} \mathrm{MgCl}, 0.1 \mu \mathrm{M}$ Pol $\beta$ and $1 \mu \mathrm{M}$ $\left[\alpha-{ }^{32} \mathrm{P}\right] \mathrm{dATP}, \mathrm{dCTP}, \mathrm{dGTP}, \mathrm{dTTP}(10 \mu \mathrm{M}$ each $)$ and $1 \mu \mathrm{M}$ partial DNA duplex. The reaction mixtures were incubated for $45 \mathrm{~min}$ at $37^{\circ} \mathrm{C}$. The reaction was further processed as described for DNA*1. The photoreactive DNA*2 was dissolved in TE buffer to a final concentration $2 \mu \mathrm{M}$.

\subsection{Photocrosslinking assays}

Photoaffinity labeling of yeast proteins with [ $\left.{ }^{32} \mathrm{P}\right]$-labeled photoreactive DNA* 1 or DNA*2 was carried out in the presence of cell free protein extracts of $S$. cerevisiae. Reaction mixtures $(20 \mu \mathrm{l}$-final volume) contained $50 \mathrm{mM}$ Tris- $\mathrm{HCl}, \mathrm{pH} 7.5,75 \mathrm{mM} \mathrm{NaCl}, 10 \mathrm{mM}$ $\mathrm{MgCl}_{2}, 100 \mathrm{nM} \mathrm{DNA}^{*} 1$ or DNA*2 and $2 \mathrm{mg} / \mathrm{ml}$ protein extracts. Photoaffinity labeling of (Ddc1-Rad17-Mec3) complex, Gst-Ddc1 or RPA with photoreactive DNA*1 or DNA*2 was carried out in reaction mixtures (15-20 $\mu \mathrm{l})$ that contained 300-750 nM (Ddc1Rad17-Mec3) complex, 150-300 nM Gst-Ddc1 or 15-200 nM RPA, $50 \mathrm{mM}$ Tris- $\mathrm{HCl}, \mathrm{pH} 7.5,50 \mathrm{mM} \mathrm{NaCl}$ and $5 \mathrm{mM} \mathrm{MgCl}_{2}$ and 100 nM DNA* 1 or DNA*2. The reaction mixtures were incubated at $30^{\circ}$ for $5 \mathrm{~min}$ and irradiated by UV light $\left(\lambda=312 \mathrm{~nm}, 1.5 \mathrm{~J} / \mathrm{cm}^{2}\right)$ on ice. A Bio-Link BLX-312 cross-linker (Vilber-Lourmat) was used as light source in all experiments. Reactions were stopped by adding SDS-sample buffer and heating for $5 \mathrm{~min}$ at $96^{\circ} \mathrm{C}$. Photocrosslinking products were separated in a 10\% SDS-PAGE [31]. The gels were dried and subjected to phosphorimaging for quantification using Molecular Imager/Quantity One software (Bio-Rad, USA) or "Typhoon" (Amersham Pharmacia Biotech, USA).

2.6. Cleavage of the RPAp70-DNA*2, RPAp70-DNA*1, RPAp32-DNA*1 or Gst-Ddc1-DNA*1 adducts in cell free extracts

To analyze the cleavage of the RPAp70, RPAp32 or Gst-Ddc1 crosslinked to DNA*1 1 or DNA*2 in cell extracts, crosslinking of purified yeast proteins was first carried out in reaction mixtures $(60-130 \mu \mathrm{l})$ that contained $50 \mathrm{mM}$ Tris- $\mathrm{HCl}, \mathrm{pH} 7.5,60 \mathrm{mM} \mathrm{NaCl}$, $10 \mathrm{mM} \mathrm{MgCl}_{2}, 100 \mathrm{nM} \mathrm{DNA}^{*} 2$ or DNA*1, $100-200 \mathrm{nM}$ yeast RPA or 150-300 nM Gst-Ddc1. The reaction mixtures were incubated at $30{ }^{\circ} \mathrm{C}$ for $5 \mathrm{~min}$ then irradiated by UV light $\left(\lambda=312 \mathrm{~nm}, 1.5 \mathrm{~J} / \mathrm{cm}^{2}\right)$ on ice. After that, aliquots $(10-50 \mu \mathrm{l})$ containing proteins crosslinked to DNA were taken and supplemented with proteins extracts at a final concentration of $0.8-1.6 \mathrm{mg} / \mathrm{ml}$. The reactions were performed at $30^{\circ} \mathrm{C}$ for $10-40 \mathrm{~min}$ and stopped by adding SDS-sample buffer and heating for $5 \mathrm{~min}$ at $96^{\circ} \mathrm{C}$. Photocrosslinking products were separated in a $10 \%$ SDS-PAGE [31]. The gels were dried and subjected to phosphorimaging for quantification as above described.

\subsection{Preparative photocrosslinking and purification of the protein-DNA adducts}

For preparative scale experiments, the bottom strand in DNA*1 and DNA*2 was 5 -biotinylated DNA. The reaction mixture $(2 \mathrm{ml})$ contained $50 \mathrm{mM}$ Tris- $\mathrm{HCl}, \mathrm{pH} 7.5,75 \mathrm{mM} \mathrm{NaCl}, 10 \mathrm{mM} \mathrm{MgCl}_{2}$, of proteins of WT cell extract $(3.0 \mathrm{mg} / \mathrm{ml}), 200 \mathrm{nM} 5^{\prime}$-biotinylated DNA* 1 or DNA*2. The mixture was incubated for $10 \mathrm{~min}$ at $30^{\circ} \mathrm{C}$ followed by UV-irradiation on ice. The reaction mixture was further incubated with $1 \mathrm{mg}$ of streptavidin paramagnetic beads for $45 \mathrm{~min}$ at room temperature with constant mild agitation. Then, the beads were processed as described [32]. Briefly, the particles were washed six times by resuspension and sedimentation with a magnet in $1 \mathrm{ml}$ of the wash buffer $1(50 \mathrm{mM}$ Tris- $\mathrm{HCl}, \mathrm{pH} 9.4,2 \mathrm{M} \mathrm{NaCl})$ and two times in $1 \mathrm{ml}$ of buffer 2 (50 mM Tris- $\mathrm{HCl}, \mathrm{pH} 7.5,75 \mathrm{mM}$ $\mathrm{NaCl}$ ). Afterward, $100 \mu \mathrm{l}$ of SDS-sample buffer was added to the paramagnetic particles followed by heating for $20 \mathrm{~min}$ at $95^{\circ} \mathrm{C}$. The sample was resolved by $10 \%$ SDS-PAGE followed by staining with Coomassie Blue. $\left[{ }^{32} \mathrm{P}\right]$-labeled crosslinked proteins were visualized by exposure to X-ray film overnight at $0^{\circ} \mathrm{C}$. Well-defined protein bands, which correspond to radioactive bands, were excised from the gel and digested in-gel using trypsin [33].

\subsection{Mass spectrometric analysis}

The tryptic peptides were extracted from the gel, stored, dried up and dissolved in $0.1 \%$ aqueous TFA directly before MALDI target spotting. The saturated solution of $\alpha$-cyano-4-hydroxycinnamic acid (HCCA) in 50\% aqueous acetonitrile containing 0.1\% TFA was used as a matrix. A sample of peptides solution was mixed with the same volume of matrix solution. About $1 \mu \mathrm{l}$ of the resulting solution was deposited on the 384 ground steel target plate and allowed to dry before being introduced into the mass spectrometer. Mass spectra were recorded using an autoflex III MALDI-TOF mass spectrometer (Bruker Daltonics Inc., Germany) equipped with a pulsed nitrogen laser $(\lambda=337 \mathrm{~nm})$ in a positive reflectron mode. Ions formed by a laser beam were accelerated to $20 \mathrm{keV}$ kinetic energy. The final spectra were obtained by accumulating about 2500 single laser shot spectra over the $m / z$ range $0,400-4,000$. External calibration in positive mode was done using Peptide Calibration Standard II. Peak lists $(\mathrm{m} / \mathrm{z})$ were extracted from data obtained using FlexAnalysis 2.4 software (Bruker Daltonik GmbH, Germany). Peaks corresponding to the matrix and trypsin autolysis products were removed from the resulting lists. Identification of proteins 


\section{FABG 5'-[32p]-GGC TTC ATCGTTGTCC \\ 3'- CCGaAGTAGCAACAGGgtctgGaccacctatgGC-5' (DNA*1)}

A

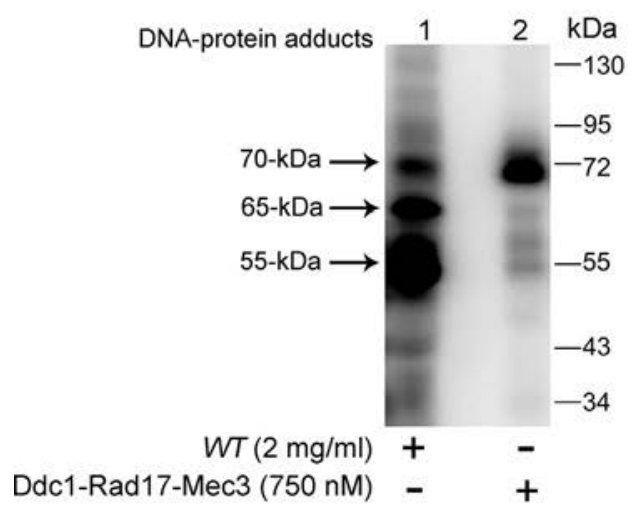

B

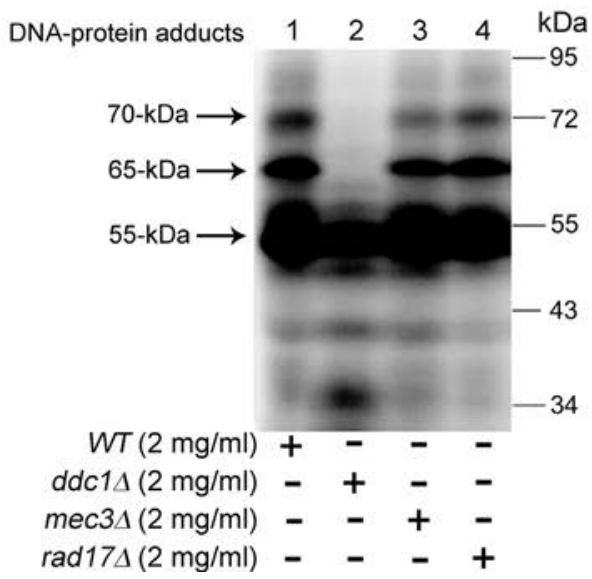

C

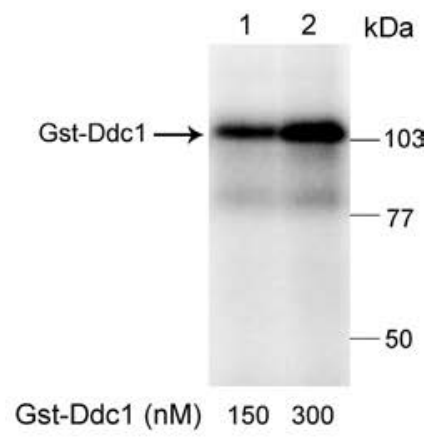

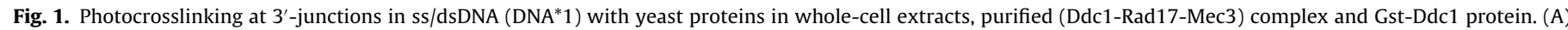

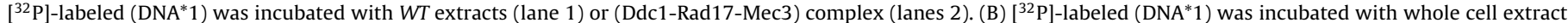

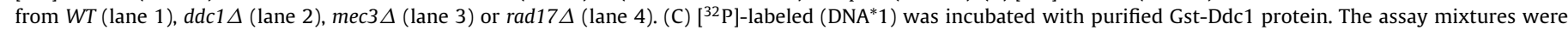

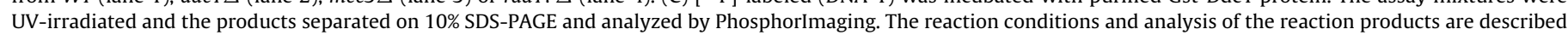
in "Section 2". The nucleotide sequence and structure of (DNA*1) is reported (Table 2).

from MALDI-TOF mass spectrum was achieved using Peptide Mass Fingerprint of Mascot (www.matrixscience.com). Monoisotopic peptide masses were searched using NCBI non-redundant database, limited to the $S$. cerevisiae proteins. The search parameters used were as follows: trypsin was given as the digestion enzyme, maximum allowed peptide mass error $\pm 230 \mathrm{ppm}$, up to two enzymatic missed cleavages.

\subsection{Analysis of stability of free RPA and Ogg1 in whole cell extracts}

To analyze the cleavage of the purified yeast RPA noncrosslinked to DNA in cell extracts, $100 \mathrm{nM}$ RPA was incubated with ddc1 $\Delta$ extract $(1 \mathrm{mg} / \mathrm{ml})$ in buffer containing $50 \mathrm{mM}$ Tris- $\mathrm{HCl}$, $\mathrm{pH} 7.5,60 \mathrm{mM} \mathrm{NaCl}, 10 \mathrm{mM} \mathrm{MgCl}$ for increasing lengths of time $(0-60 \mathrm{~min})$ at $30^{\circ} \mathrm{C}$. At each time, aliquots $(20 \mu \mathrm{l})$ were taken and

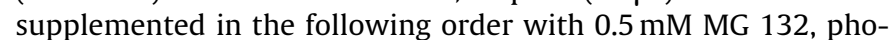
toreactive $\mathrm{DNA}^{*} 2,200 \mathrm{nM}$-final concentration, and immediately UV-irradiated for $5 \mathrm{~min}$ at $4{ }^{\circ} \mathrm{C}$.

Alternatively, the stability of endogenous RPA or Ogg1 in whole cell extracts was analyzed by Western blot. Proteins in cell free extracts $(25 \mu \mathrm{g}$ in $10 \mu \mathrm{l})$ were supplemented with $5 \mu \mathrm{l}$ of SDSsample buffer followed by heating for $5 \mathrm{~min}$ at $95^{\circ} \mathrm{C}$. The samples were resolved by $12.5 \%$ SDS-PAGE followed by staining with Coomassie blue. Western blot analysis was performed as follows. Proteins ( $25 \mu \mathrm{g}$ in $10 \mu \mathrm{l}$ ) of yeast extracts were separated by $12.5 \%$ SDS-PAGE and transferred onto nitrocellulose membranes. The membranes were stained with Ponceau S, incubated with blocking solution $0.1 \%$ Tween-20 in PBS-buffer (PBS-T) containing 5\% non-fat dry milk and polyclonal rabbit anti-RPA antibody (dilution of 1:3000, v/v) or anti-Ogg1 antibody (dilution of 1:2000,v/v) for $30 \mathrm{~min}$ at room temperature. The membranes were washed three times with PBS-T and incubated with horseradish peroxidaseconjugated secondary antibody (dilution of 1:50000, v/v). RPA and Ogg1 was revealed with ECL detection system according to the manufacturer's protocol and exposed to X-ray film (HyperfilmECL).

\section{Results}

\subsection{Interaction of Ddc1 and RPAp70 with $3^{\prime}$ - and 5'-single-stranded/double-stranded DNA junctions}

To identify yeast proteins that interact with partial DNA duplexes, we used $\left[{ }^{32} \mathrm{P}\right]$-labeled photoreactive DNA probes (Table 2). Incubation of the $3^{\prime}$-junction substrate (DNA*1) with $W T$ yeast whole cell protein extract, followed by near-UV light exposure, resulted in labeling of several DNA-protein adducts with the apparent molecular masses of about 70-, 65- and 55-kDa (Fig. 1A, lane 1). A similar pattern was observed using a DNA probe with a photoreactive group at the margin of a nick [25]. In this former study, we identified a 65-kDa adduct that contains Ddc1, a member of the (Ddc1-Rad17-Mec3) clamp [25]. Thus, Ddc1 was a good candidate for the protein partner involved in $65-\mathrm{kDa}$ or $70-$ kDa DNA-protein adducts observed with DNA*1. Photocrosslinking of purified (Ddc1-Rad17-Mec3) with DNA*1 reveals DNA-protein adducts migrating with apparent molecular masses of 70-kDa, 65$\mathrm{kDa}$ and $55-\mathrm{kDa}$ (Fig. 1A, lane 2). The 70-kDa product being much more abundant than the lower molecular weight products, which suggests that crosslinking primarily occurs between Ddc1 (69.7$\mathrm{kDa}$ ) and the $3^{\prime}$-junction substrate (Fig. $1 \mathrm{~A}$, lane 2 ). On the other hand, minor products migrating at 65-kDa and 55-kDa may correspond to Ddc1 degradation products or Mec3 (53.1-kDa) or Rad17 (45.6-kDa) products (Fig. 1A, lane 2). To characterize the protein(s) crosslinked to DNA* 1 in $W T$ extract, we used biotinylated DNA*1 for isolation of crosslinked proteins followed by MALDI-TOF MS analysis. The 70-kDa adduct was excised from gel and subjected to in-gel trypsinolysis followed by extraction of peptides [25,32,33]. The mixture of peptides was analyzed by MALDI-TOF MS and the data were analyzed using MASCOT PMF search engine [34]. Ten of peptide-[MH] ${ }^{+}$ions, corresponding to peptides in Ddc1, were observed by MALDI-TOF mass spectrum (Table 3). Based on these PMF data, Ddc1 was identified as first-ranked protein with a Mascot probability score of 122 (sequence coverage 14\%). Taken together, the results identify Ddc1 as the major protein crosslinked to 3'junction (DNA*1). We also compared photocrosslinking products 
Table 3

Observed masses in MALDI-TOF mass spectrum, which correspond in mass to theoretical tryptic peptides of Ddc1.

\begin{tabular}{rrll}
\hline${ }^{\mathrm{a}}(\mathrm{M}+\mathrm{H})^{+}$obs & $(\mathrm{M}+\mathrm{H})^{+}$calc & Ddc1 peptides & Position \\
\hline 1379.7860 & 378.7860 & YDPIIINLKYK & $157-167$ \\
546.2860 & 545.2921 & QDKR & $307-310$ \\
926.6440 & 925.5318 & RSHSKRR & $310-316$ \\
848.3830 & 847.5531 & SIIFKLK & $321-327$ \\
558.3070 & 557.3173 & NSPLK & $435-439$ \\
575.3650 & 574.2823 & NNTAR & $457-461$ \\
1675.8340 & 1674.7519 & ALPAADDEVSCSNIDR & $547-562$ \\
704.5280 & 703.4414 & KGMLKK & $563-568$ \\
517.2180 & 516.3271 & EKLK & $569-572$ \\
2186.8510 & 2186.0637 & QDNKEMEDGLGLTQVEKPR & $590-608$ \\
\hline
\end{tabular}

a Peptides matched/percent coverage/Mascot probability score - 10/14/122.

with DNA 1 in $W T, d d c 1 \Delta$, mec $3 \Delta$ and rad 17 cell protein extracts. As expected, the pattern of DNA-protein adducts with $d d c 1 \Delta$ extract is clearly different from $W T$, since $70-\mathrm{kDa}$ and $65-\mathrm{kDa}$ adducts, which primarily contain Ddc1, are not observed (Fig. 1B, lanes 1,2). On the other hand, the patterns of DNA-protein adducts are similar in $W T$, mec $3 \Delta$ and rad $17 \Delta$ extracts (Fig. $1 \mathrm{~A}$, lane 1 and $\mathrm{B}$, lanes $1,3,4$ ). We conclude that Ddc1 interacts with 3 '-junctions under conditions when (9-1-1) clamp cannot be formed. Gst-Ddc1 fusion protein was also tested for its ability to form protein-DNA*1 adducts in vitro. We found that Gst-Ddc1 alone is effectively crosslinked to DNA*1 (Fig. 1C). To sum up, Ddc1 is able to interact with $3^{\prime}$-junctions, independently of Mec3 or Rad17, the other components of the (9-1-1) clamp.

When [ $\left.{ }^{32} \mathrm{P}\right]$-labeled photoreactive $5^{\prime}$-junction substrate (DNA*2) was reacted with WT extract, we observed DNA-protein adducts with apparent molecular masses about 80-kDa, 72-kDa, 65-kDa and 55-kDa (Fig. 2A, lane 1). Comparison of photocrosslinking products formed with $\mathrm{DNA}^{*} 1$ or $\mathrm{DNA}^{*} 2$ reveals significant differences and suggests different partner protein(s). Indeed, reaction of $W T$ extract with DNA*2 exhibits a major DNA-protein adduct with an apparent mass of $80-\mathrm{kDa}$, which is poorly represented in reaction with $\mathrm{DNA}^{*} 1$. Since, the (9-1-1) checkpoint clamp
Table 4

Observed masses in MALDI-TOF mass spectrum, which correspond in mass to theoretical tryptic peptides of p70 subunit of RPA.

\begin{tabular}{cllc}
\hline${ }^{\mathrm{a}}(\mathrm{M}+\mathrm{H})^{+}$obs & $(\mathrm{M}+\mathrm{H})^{+}$calc & RPA p70 peptides & Position \\
\hline 2031.1370 & 2029.9606 & QRYDNPTGGVYQVYNTR & $19-35$ \\
1747.0010 & 1745.8009 & YDNPTGGVYQVYNTR & $21-35$ \\
1592.9500 & 1591.8140 & FQSMELQRGDIIR & $69-81$ \\
1625.0280 & 1623.8257 & LFNVNFLDTSGEIR & $221-234$ \\
2495.4970 & 2494.2968 & LQPAKPQFTNLTHPYELNLDR & $262-282$ \\
1188.8080 & 1187.7139 & FIAQRITIAR & $443-452$ \\
1644.9800 & 1643.7613 & ITQSIQMNEYDFR & $566-578$ \\
1450.9340 & 1449.7364 & YTVANLHSLNYR & $594-605$ \\
\hline
\end{tabular}

a Peptides matched/percent coverage/Mascot probability score - 8/16/125.

can interact with both $3^{\prime}$ - and $5^{\prime}$-DNA junctions in vitro $[14,16]$, we also performed photocrosslinking of DNA* 2 with the purified (Ddc1-Rad17-Mec3) complex. The data show that the (9-1-1) complex reacts relatively poorly with $\mathrm{DNA}^{*} 2$ and do not form a prominent DNA-protein adduct of $80-\mathrm{kDa}$ (Fig. 2A, lane 2). These data suggest that the $80-k D a$ DNA-protein adduct observed with (DNA*2) does not involve Ddc1. To identify the protein present in the $80-\mathrm{kDa}$ adduct, we performed MALDI-TOF MS analysis. Eight of peptide- $[\mathrm{MH}]^{+}$ions, corresponding to peptides of the 70-kDa large subunit of yeast replication protein A (RPAp70), were observed in MALDI-TOF mass spectrum (Table 4). Based on these peptide mass fingerprint data, RPAp70 was identified as first-ranked protein with a Mascot probability score of 125 (sequence coverage 16\%). These data show that the $80-\mathrm{kDa}$ DNA-protein adduct is primarily composed of RPAp70 crosslinked to DNA*2. We also compared photocrosslinking of DNA*2 in $W T$, ddc $1 \Delta, \operatorname{mec} 3 \Delta$ and $\operatorname{rad} 17 \Delta$ whole cell free extracts. Fig. $2 \mathrm{~B}$ shows that similar patterns are obtained using $W T$, mec $3 \Delta$ and rad $17 \Delta$ extracts (lanes $1,3,4$ ). In contrast, the pattern of photocrosslinking to $\mathrm{DNA}^{*} 2$ in $\operatorname{ddc} 1 \Delta$ extract is greatly modified compared to $W T$, with the complete disappearance of the $80-\mathrm{kDa}$ adduct (Fig. 2B, lanes 1,2). This last result might suggest the presence of Ddc1 in the $80-\mathrm{kDa}$ adduct, which is rather contradictory with our identification of RPAp70

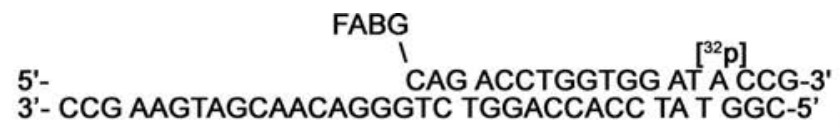

$\left(\mathrm{DNA} \mathrm{A}^{*}\right)$

A

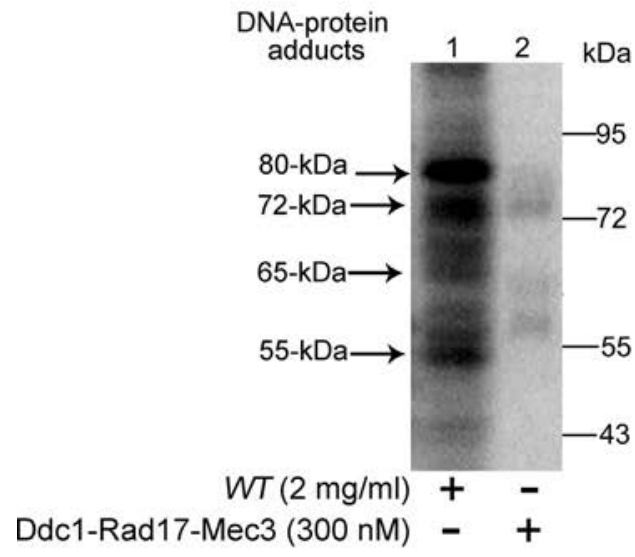

B

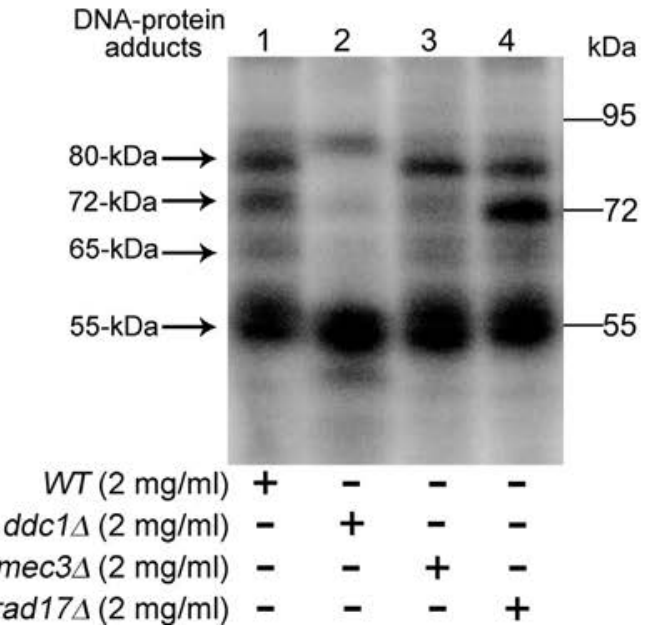

C

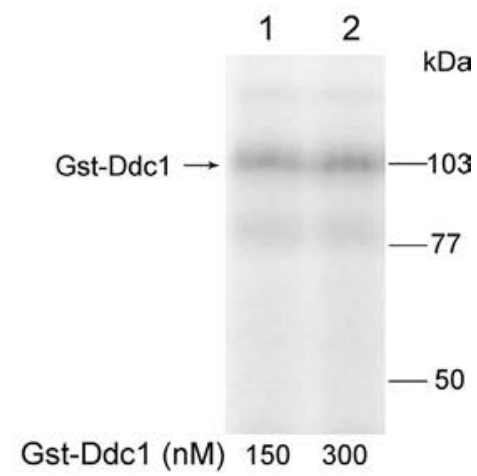

Gst-Ddc1 (nM) $150 \quad 300$

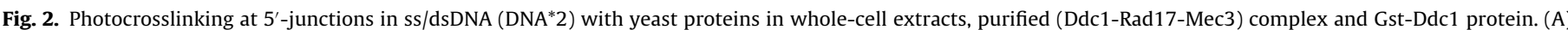

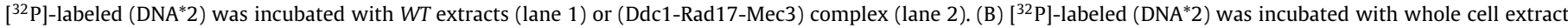

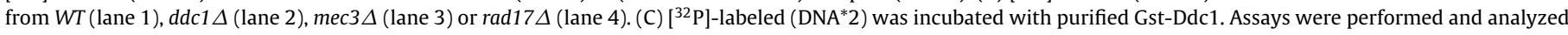
as described in Fig. 1. The nucleotide sequence and structure of (DNA*2) is reported (Table 2). 


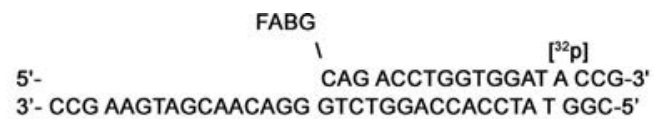

A

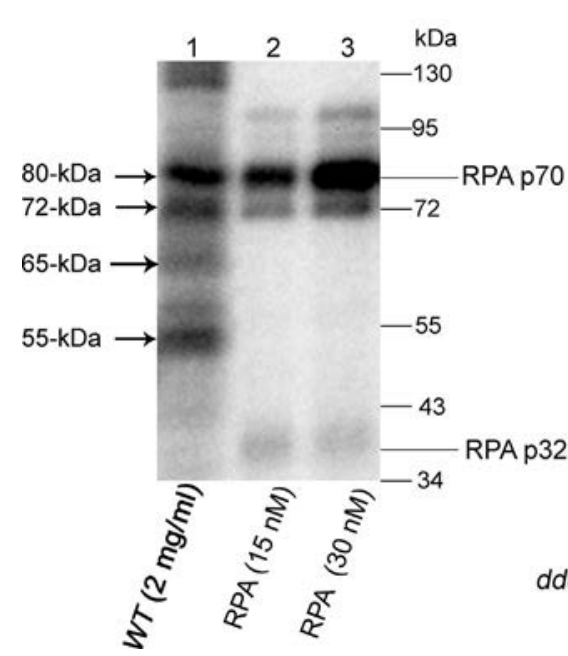

B

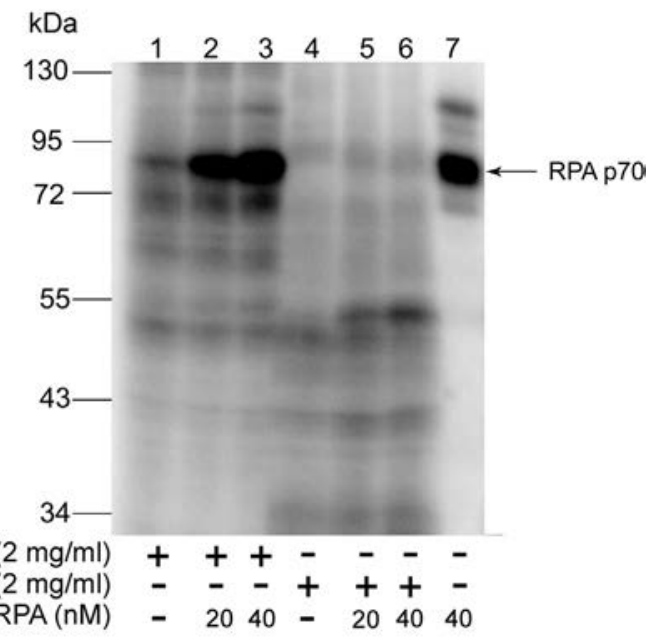

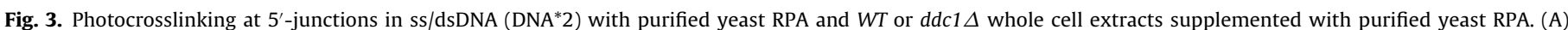

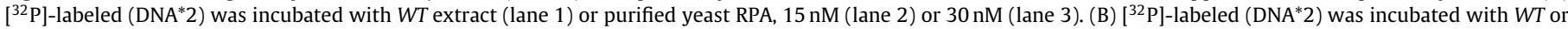

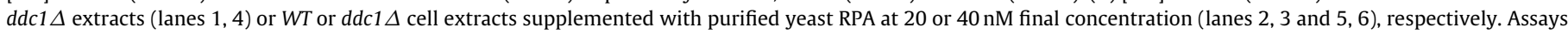
were performed and analyzed as described in Fig. 1.

(Table 4). Finally, we tested the capacity of Gst-Ddc1 alone to be photocrosslinked at $5^{\prime}$-junctions. Fig. $2 \mathrm{C}$ shows that Gst-Ddc1 reacts with a $5^{\prime}$-junction DNA, but with a low efficiency compared to a $3^{\prime}$-junction DNA (compare: Figs. $1 \mathrm{C}$ and $2 \mathrm{C}$ ). This last result suggests a low affinity of Ddc1 for $5^{\prime}$-junction DNA in our assay conditions and points to the presence of another factor (RPAp70) than Ddc1 in the major $80-\mathrm{kDa}$ adduct revealed in WT extracts (Fig. 2B).

Presumably, the absence of Ddc1 in the extract impacts the formation or/and stability of the RPAp70-DNA*2 adduct, as already reported for the Topoisomerase I-DNA adduct using nickcontaining DNA probes [25]. To support this hypothesis, we incubated purified yeast RPA (the three subunits complex; RPAp70, RPAp32 and RPAp14) [35] and photoreactive DNA*2. Fig. 3A shows that the mobility of RPAp70 labeled with DNA*2 is consistent with the 80-kDa DNA-protein adducts observed in WT extract. The data also show that RPAp32 is not efficiently crosslinked to DNA*2, compared to RPAp70 (Fig. 3A, lanes 2, 3). The predominant labeling of RPAp70 by DNA containing $5^{\prime}$-junctions is in accordance to the model of polar $\left(5^{\prime} \rightarrow 3^{\prime}\right)$ binding of RPA with ssDNA [36-38]. It was shown earlier for mammalian RPA that subunit p70 interacts with recessed $5^{\prime}$-end at ss/dsDNA junctions [36,38]. We also show that the addition of purified yeast RPA in WT extract results in accumulation of RPAp70-DNA*2 adducts (Fig. 3B, lanes 1-3). In contrast, the addition of purified yeast RPA in $d d c 1 \Delta$ extract does not show accumulation of RPAp70-DNA*2 (Fig. 3B, lanes 4-6). Therefore, we conclude that RPA strongly interacts with $5^{\prime}$-junctions in $W T$ yeast cell free extracts yielding a major photocrosslinking product, RPAp70-DNA*2, which is not observed in $d d c 1 \Delta$ extracts.

\subsection{Proteolysis of RPAp70 covalently bound to $D N A^{*} 2$ in $d d c 1 \Delta$ extract}

The data show that Ddc1 directly or indirectly impacts the formation or/and the stability of the RPAp70-DNA*2 adduct (Figs. 2B and 3B). To explore this avenue, we preformed RPAp70DNA* 2 adduct by reacting purified yeast RPA and DNA* 2 followed by UV-irradiation (Fig. 4A, lane 1). The stability of the preformed RPAp70-DNA*2 adduct was examined in the presence of $d d c 1 \Delta$, $\operatorname{rad} 17 \Delta$, mec $3 \Delta$ or $W T$ extracts (Fig. 4 A, lanes $2-13$ ). We found that RPAp70-DNA* 2 was progressively cleaved yielding a product of about $50-\mathrm{kDa}$ (p50) in the presence of ddc1 $\Delta$ extract (Fig. 4A, lanes $2-4$, Fig. 4B), whereas it was stable in $\operatorname{rad} 17 \Delta$, mec $3 \Delta$ or $W T$ extracts (Fig. 4A, lanes 5-13, Fig. 4B). Finally, the proteolytic cleavage of RPAp70 covalently bound to DNA*2 is not observed in the mec1 $\Delta$ extract (Supplementary Fig. S1), suggesting a role for Ddc1 independently of the DNA checkpoint response initiated by its phosphorylation by the Mec1/ATR kinase [8]. These results point to a unique role for Ddc1 in the prevention of the proteolytic degradation of RPAp70-DNA*2, independent of the other subunits of the (9-1-1) clamp and the checkpoint response.

Supplementary Fig. I related to this article can be found, in the online version, at http://dx.doi.org/10.1016/j.dnarep.2014.07.002.

To characterize the type of proteolytic activity responsible for the degradation of RPAp70-DNA*2, the effect of protease inhibitors, E64, pepstatine A, $o$-phenanthroline or AEBSF and proteasome inhibitor, MG 132, was tested (Fig. 4C and D, lanes 2-7). The results show that only MG 132 exhibits a significant inhibitory effect, which suggests proteolysis mediated by the proteasome. To further investigate the mechanisms of RPAp70-DNA*2 degradation in $d d c 1 \Delta$ extracts, we measured its cleavage in a mixture of $W T$ and ddc1 $\Delta$ extracts (Fig. $5 \mathrm{~A}$ and B). Fig. $5 \mathrm{~A}$ and $\mathrm{B}$ shows that the degradation was noticeably delayed when $d d c 1 \Delta$ extract was supplemented with $W T$ extract. This result suggests the presence of factor(s) in the WT extract that prevent the degradation by the proteasome of RPAp70 covalently linked to DNA, which are not present or functional in $d d c 1 \Delta$ strains. At that stage of investigation, the role of Ddc1 may be direct or indirect. Therefore, we measured the degradation of the RPAp70-DNA*2 adduct in $d d c 1 \Delta$ extracts supplemented with purified Gst-Ddc1 (Fig. 5C and D). The results show that the cleavage of RPAp70-(DNA*2) was only slightly reduced when incubation was performed in the presence of $d d c 1 \Delta$ extract supplemented with purified Gst-Ddc1 (Fig. 5C and D). These results are not in favor of a direct role of Ddc1 in the prevention of 
A

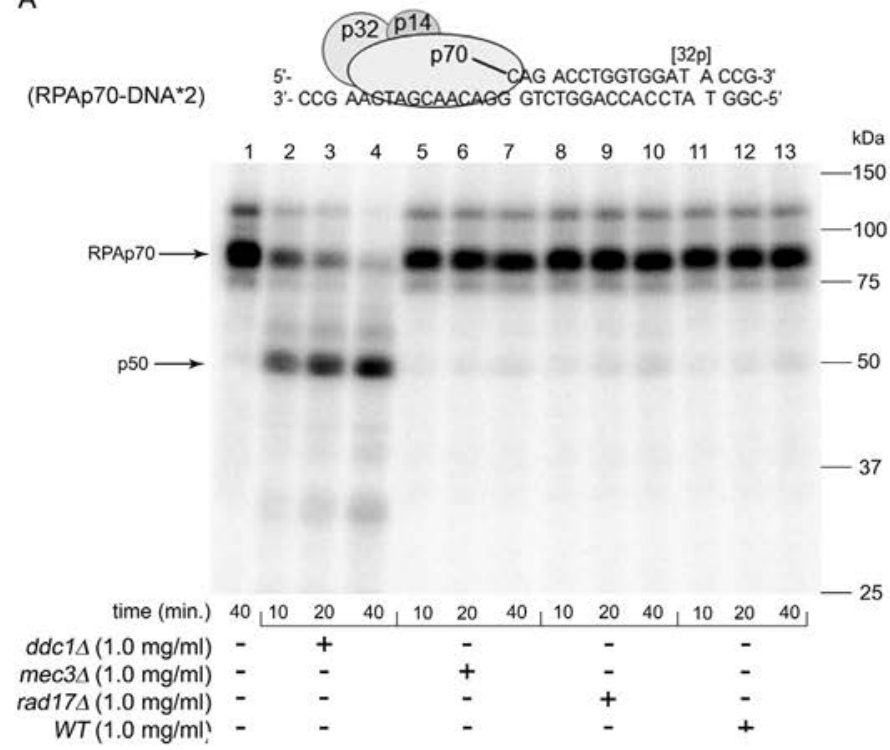

C

(RPAP70-DNA*2)
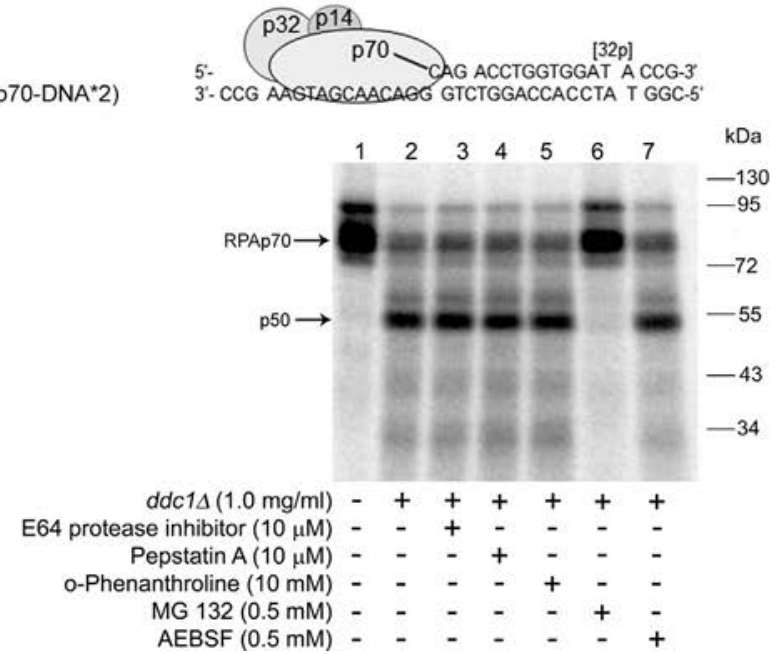

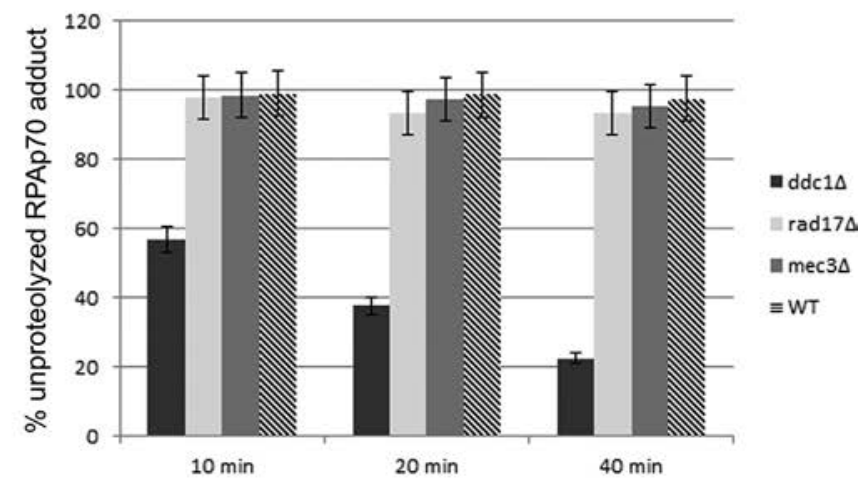

D

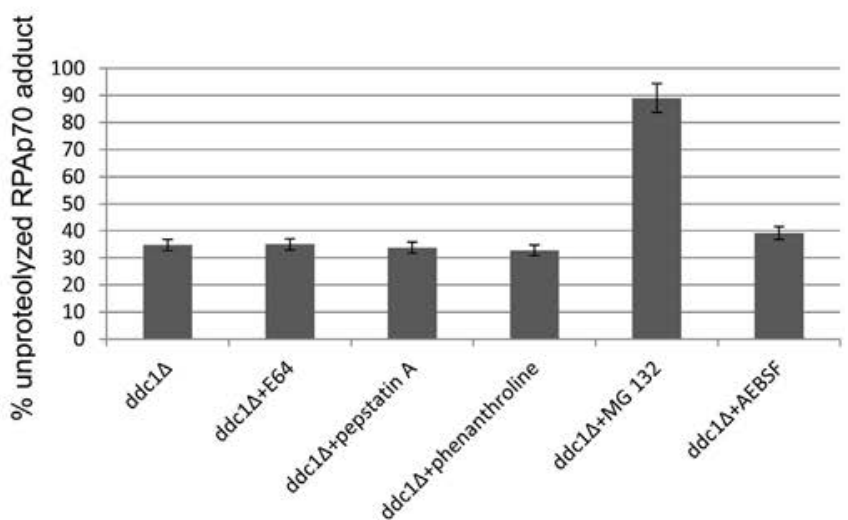

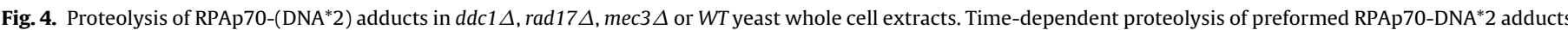

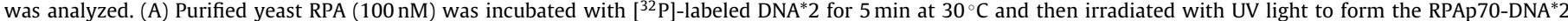

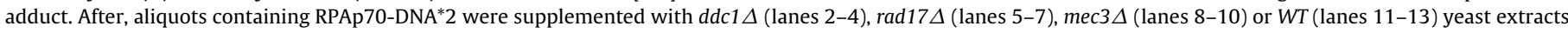

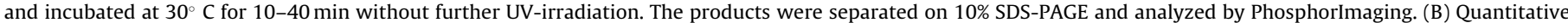

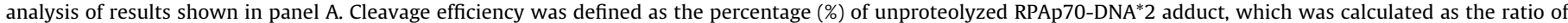

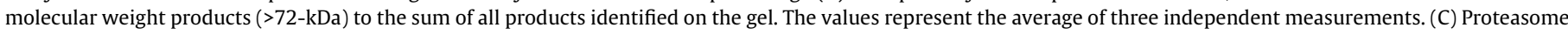

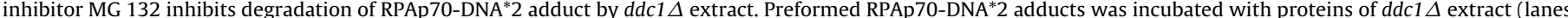

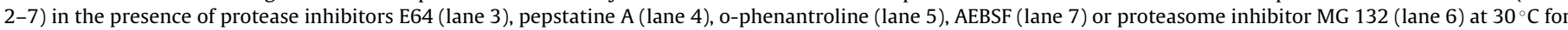

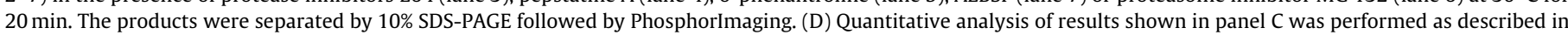
section B of the legend. An artistic representation of RPA crosslinked to DNA*2 is presented with the RPAp70 subunit linked to DNA.

the degradation by the proteasome of RPAp70 already crosslinked to DNA*2.

\subsection{Proteolysis of RPAp70 also occurs without photocrosslinking to DNA in ddc1 $\triangle$ extracts}

Our data show that preformed RPAp70-DNA* 2 crosslink is subject to proteolysis in $d d c 1 \Delta$ extracts yielding a limit product of about $50-k D a$. However, these data do not exclude the possibility of the proteolytic cleavage of RPAp70, either as a free protein or non-covalently bound to DNA. To challenge this possibility, exogenous RPA was incubated with $d d c 1 \Delta$ extract for increasing lengths of time, before adding MG 132 and [ $\left.{ }^{32} \mathrm{P}\right]$-labeled $\mathrm{DNA}^{*} 2$ to the mixture, followed by UV-irradiation on ice to limit degradation of
RPAp70-DNA adducts. Indeed, the degradation of RPAp70-DNA*2 is minor, when UV-irradiation occurs immediately after mixing RPA and $d d c 1 \Delta$ extract (Fig. 6, lane1). In contrast, analysis of photocrosslinking products after incubation of RPA in ddc1 $\Delta$ extract reveals a time dependent disappearance of the RPAp70-DNA*2 adducts and the progressive appearance of two products with molecular mass of 50-kDa and 30-kDa, respectively (Fig. 6, lanes 2-6). These data strongly suggest that the cleavage of RPAp70 also occurs before photocrosslinking to DNA*2 in ddc1 $\Delta$ extract, and that the RPAp70 degradation products formed are still able to be crosslinked to DNA*2.

However, using exogenous RPA in the context of photocrosslinking assay (Fig. 6) does not allow unambiguous conclusion about the fate of endogenous RPAp70 in $d d c 1 \Delta$ extracts. To further explore 
A

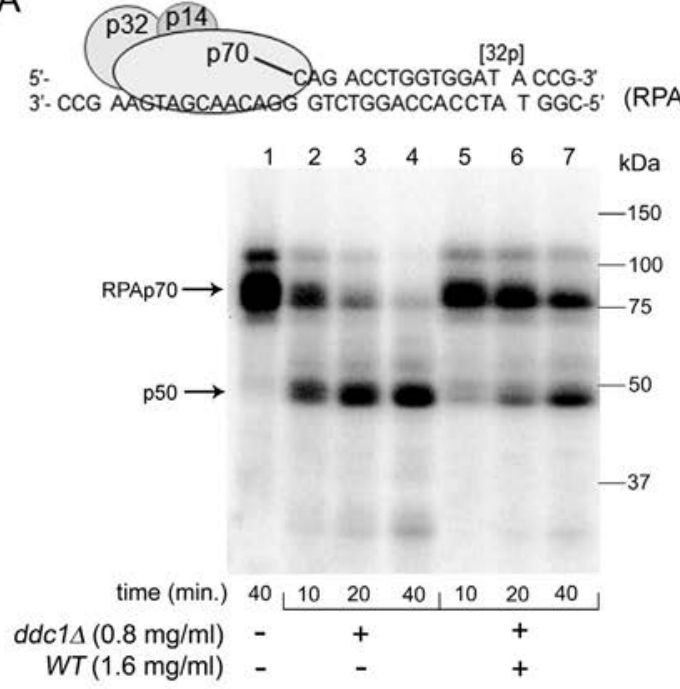

C
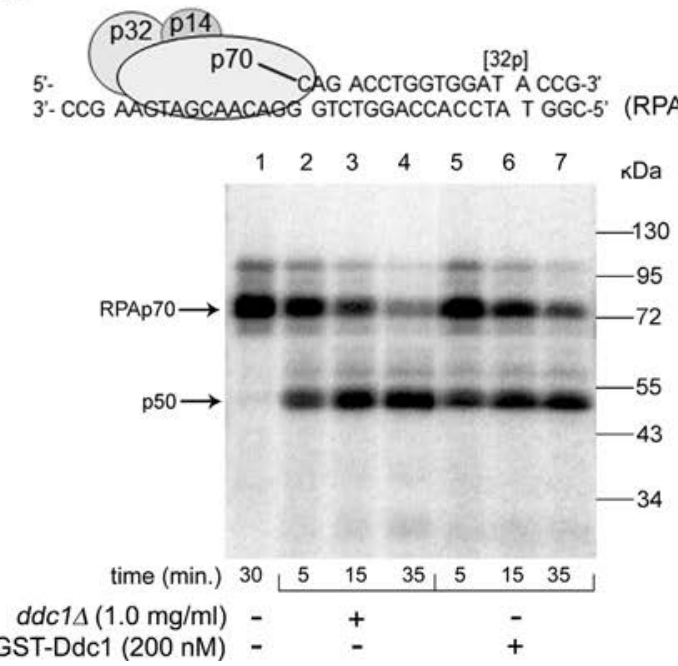

RPAp70-DNA*2)
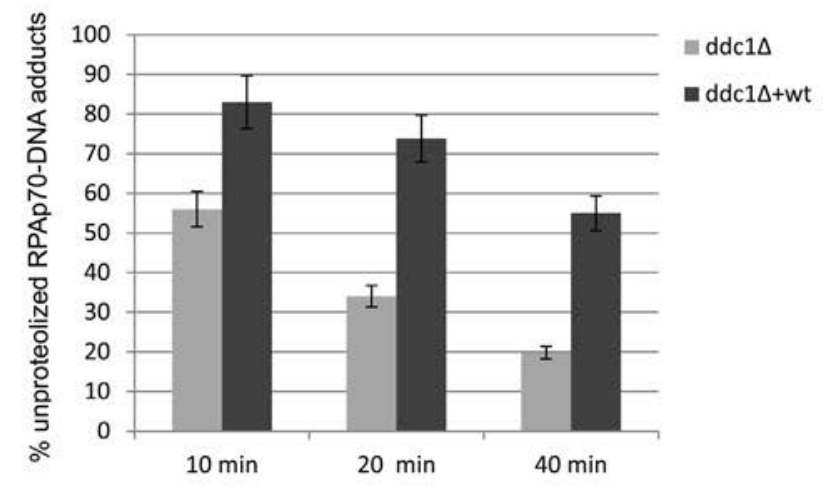

D

RPAp70-DNA*2)

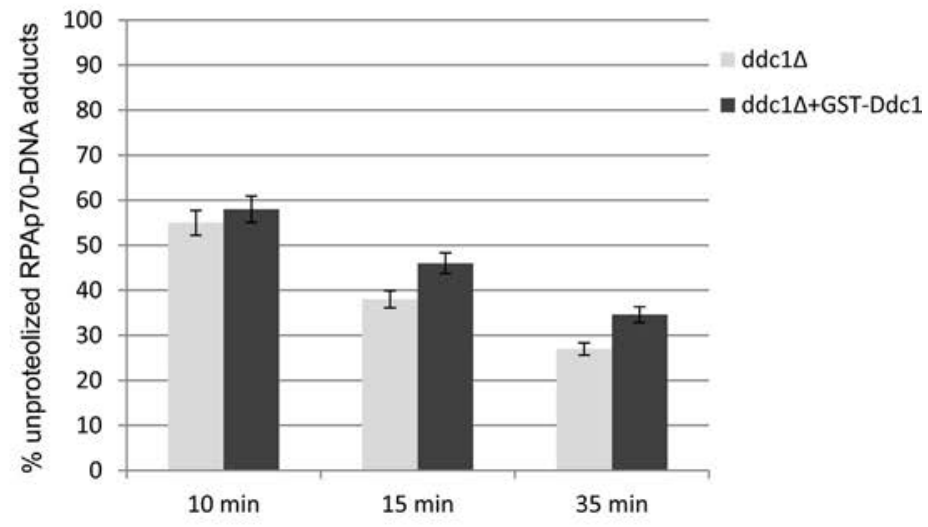

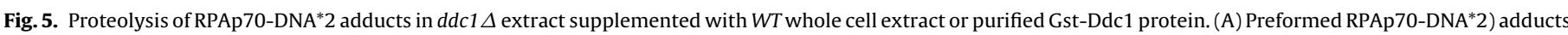

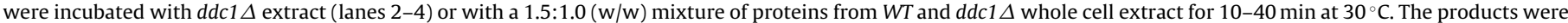

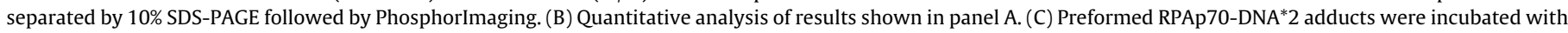
$d d c 1 \Delta$ extract (lanes 2-4) or ddc1 $\Delta$ extract supplemented with purified Gst-Ddc1 (200 nM). (D) Quantitative analysis of results shown in panel C.

the impact of Ddc1 on the stability of RPA, we performed Western blot analysis of yeast protein extracts with anti-RPA antibodies (Figs. 7 and 8). Since inactivation of Ddc1 results in proteolysis of proteins such as RPAp70, it was important to compare overall pattern of proteins in $W T$ and $d d c 1 \Delta$ extracts. Fig. $7 \mathrm{~A}$ shows that overall patterns are very similar in $W T$ and $d d c 1 \Delta$ extracts. Furthermore, incubation of $W T$ and $d d c 1 \Delta$ extracts at $30^{\circ} \mathrm{C}$ in photocrosslinking buffer, without photoreactive DNA, does not result in major changes (Fig. 7A, lanes $1-3$ and 5-8). Western blot analysis using anti-RPA antibodies reveals that RPAp70 and RPAp32 are detectable and stable upon incubation at $30^{\circ} \mathrm{C}$ in $W T$ extracts (Fig. 7B, lanes 1-3). In contrast, RPAp70 in $d d c 1 \Delta$ extract undergoes proteolysis upon incubation at $30^{\circ} \mathrm{C}$. After $1 \mathrm{~h}$ at $30^{\circ} \mathrm{C}$, RPAp70 is nearly completely converted into products of about 50$\mathrm{kDa}$ (p50) or 25-kDa (p25) (Fig. 7B, lanes 5-7). Importantly, MG 132 greatly reduces the proteolysis of RPAp70 in ddc1 $\Delta$ extract (Fig. 7B, lane 8). Finally, RPAp32 appears to be rather stable compared to RPAp70 in ddc1 $\Delta$ extract (Fig. 7B). The higher stability of RPAp32 in ddc1 $\Delta$ extracts was also observed using a DNA probe with a $3^{\prime}$-junction (DNA*1). When RPA was reacted with DNA*1 two major photocrosslinking products are formed, corresponding to RPAp70DNA*1 and RPAp32-DNA*1 (Supplementary Fig. S2A, lane 1). The RPAp70 and RPAp32 labeling by DNA*1 is in accordance to proposed model of polar $\left(5^{\prime} \rightarrow 3^{\prime}\right)$ binding of RPA with $3^{\prime}$-junctions [36-38]. Both products, RPAp70-DNA*1 and RPAp32DNA* 1 are essentially stable when incubated in the presence of the $W T$ extract (Supplementary Fig. S2A and B). In contrast, incubation in the presence of $d d c 1 \Delta$ extracts results in a significant proteolysis of RPAp70-DNA*1, whereas RPAp32-DNA*1 remains essentially intact (Supplementary Fig. S2A and B). These results support the conclusion that the main target for proteolysis in $d d c 1 \Delta$ in the case of RPA is its large subunit RPAp70.

Supplementary Fig. II related to this article can be found, in the online version, at http://dx.doi.org/10.1016/j.dnarep.2014.07.002.

In this study, we also show that the overall pattern of yeast proteins in $W T$, ddc $1 \Delta$ (clamp subunit), $\operatorname{rad} 17 \Delta$ (clamp subunit) and rad24 $\Delta$ (clamp loader) whole cell extracts are very similar and essentially stable upon incubation for $30 \mathrm{~min}$ at $30^{\circ} \mathrm{C}$ (Fig. $8 \mathrm{~A}$, 


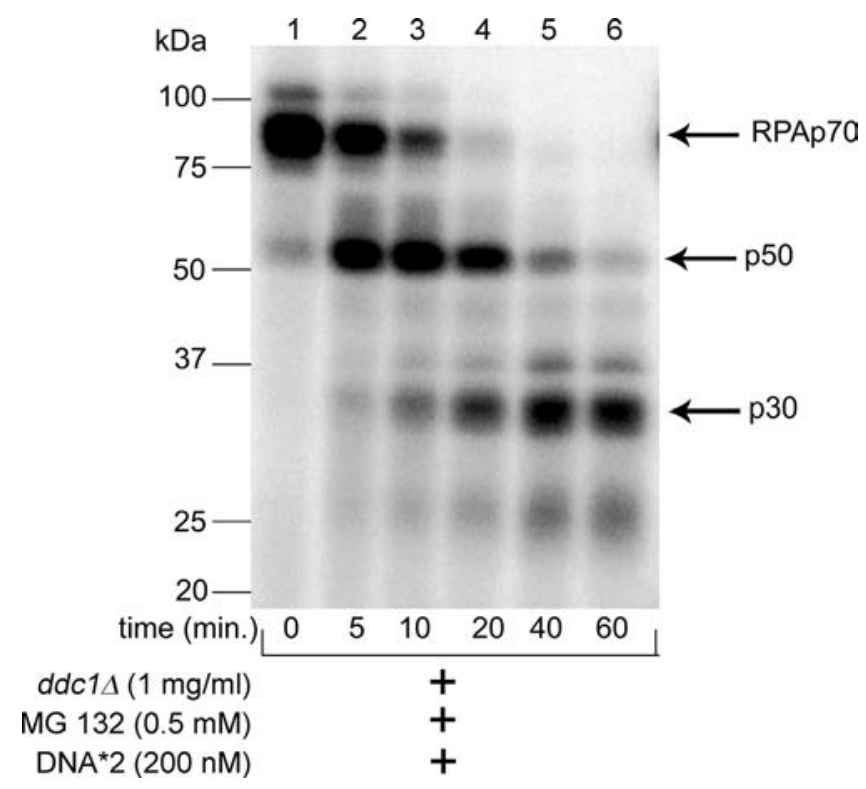

Fig. 6. Proteolysis of RPAp70 not covalently linked to DNA in ddc1 $\Delta$ whole cell extract. Purified yeast RPA $(100 \mathrm{nM})$ was incubated with $d d c 1 \Delta$ extract for increasing lengths of time $(0-60 \mathrm{~min})$ at $30^{\circ} \mathrm{C}$. At each time, the reaction was supplemented in the following order with MG 132, photoreactive DNA*2 and immediately UVirradiated for $5 \mathrm{~min}$ at $4{ }^{\circ} \mathrm{C}$. The addition of MG 132 should prevent the degradation of DNA-protein adducts after photocrosslinking. Therefore, low molecular weight products $(<70-\mathrm{kDa})$ identified after separation on $10 \%$ SDS-PAGE most likely reflect the photocrosslinking of already cleaved RPAp70.

lanes 1-8). In addition, Western blot analysis reveals that the four strains present detectable level of RPAp70 in whole cell extracts (Fig. 8B, lanes 1, 3, 5, 7). However, ddc1 $\Delta$ extract presents higher levels of RPAp70 degradation products (molecular mass $<70-\mathrm{kDa}$ ) than the three other strains (Fig. 8B, lane 3). After incubation for $30 \mathrm{~min}$ at $30^{\circ} \mathrm{C}$ in photocrosslinking buffer without DNA*2, the amount of RPAp70 is significantly reduced ( $>2$-fold) in $d d c 1 \Delta$ extract (Fig. 8B, lanes 3,4), whereas it appears stable in other extracts (Fig. 8B). As already discussed (Fig. 7B), the diminution of RPAp70 is accompanied by the accumulation of p50 and p25 products. Taken together, these data strongly suggest that Ddc1 prevents proteasome-mediated proteolysis of RPAp70, not covalently attached to DNA (free or non-covalently bound to DNA), independently of the presence of Rad17 (member of the (9-1-1) clamp) or the clamp loader $\operatorname{Rad} 24$.

\section{Discussion}

Partial DNA duplexes containing 3'- or 5'-ss/dsDNA junctions are important intermediates in the course of DNA repair and replication $[2,3,7]$. The recognition of these structures by specific proteins is a critical event leading to DNA damage responses in S. cerevisiae [24,39-41]. In the present study, we show that the component of the checkpoint clamp (9-1-1), Ddc1, was found to be preferentially photocrosslinked to $3^{\prime}$-junctions (DNA*1) in $W T$ whole cell protein extracts (Table 3 ). Although, Ddc1 alone (Gst-Ddc1) can be crosslinked to DNA*1, we do not exclude the possibility to crosslink the trimeric form of the (9-1-1) clamp via its Ddc1 subunit in WT extracts. Finally, Ddc1 can also be crosslinked at $5^{\prime}$-ss/dsDNA junctions with low affinity (Fig. 2). In the case of $5^{\prime}$-junctions (DNA*2), RPA was found to be predominantly photocrosslinked to the DNA probe through its large subunit RPAp70 in WT whole cell protein extract (Table 4). Labeling of the RPAp70 and RPAp32 by 3'-junction (DNA*1) were not detected in WT extract. However, RPAp70 and RPAp32 are efficiently crosslinked to $3^{\prime}$-junction in assays using purified RPA and DNA*1 (Supplementary Fig. S2A). These results point to a preferential, but non-exclusive, binding of Ddc1 and RPA to $3^{\prime}$ - and $5^{\prime}$-junctions in yeast whole cell extracts, respectively.

More surprising was the impact of Ddc1 on the formation or/and stability of the RPAp70-DNA2* photocrosslinking product (Figs. 2 and 3). The crosslinking assay results show that RPAp70 covalently bound to $\mathrm{DNA}^{*} 2$ is stable upon incubation at $30^{\circ} \mathrm{C}$ in $W T$, rad17 $\Delta$ (clamp subunit), mec $3 \Delta$ (clamp subunit), rad24 $\Delta$ (clamp loader) and mec1 $\Delta$ (checkpoint sensor) extracts, whereas it is quantitatively converted into a 50-kDa product (p50) upon incubation at $30^{\circ} \mathrm{C}$ in $d d c 1 \Delta$ extract (Fig. $4 \mathrm{~A}$ and B and Supplementary Fig. S1). Thus, in contrast to other "checkpoint sensor" proteins, absence of Ddc1 in the whole cell extract leads to the proteolysis of RPAp70. Furthermore, the proteasome inhibitor MG 132 greatly reduces the cleavage of RPAp70 attached to DNA*2 in $d d c 1 \Delta$ extract (Fig. 4B). These results strongly suggest that RPAp70 covalently attached to $5^{\prime}$-junctions in ss/dsDNA is a target for proteasome that cleaves RPAp70 moiety at a preferential site in $d d c 1 \Delta$ whole cell extract. To further explore how Ddc1 impacts cleavage of RPAp70-DNA adduct, we measured its stability upon the addition of WT extract or purified Gst-Ddc1 to $d d c 1 \Delta$ extract. The results show that factor(s)
A

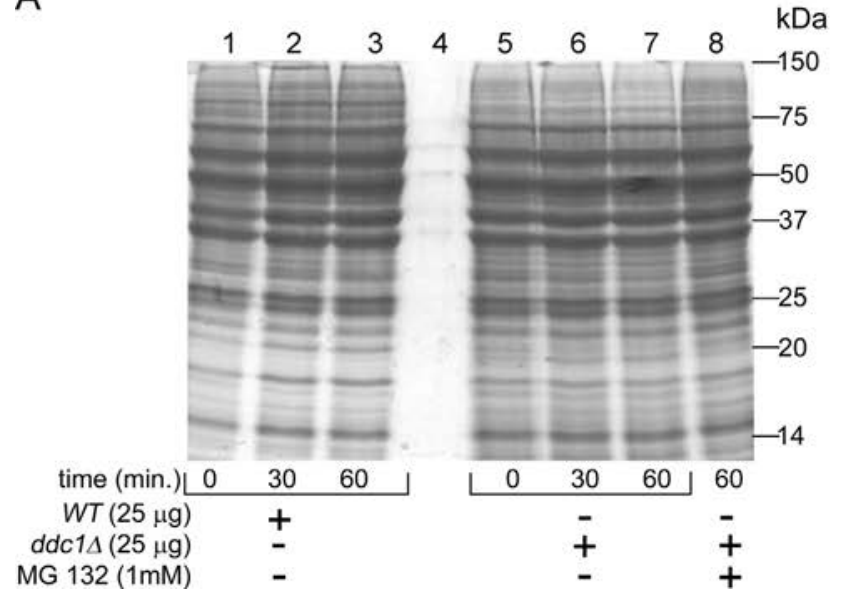

B

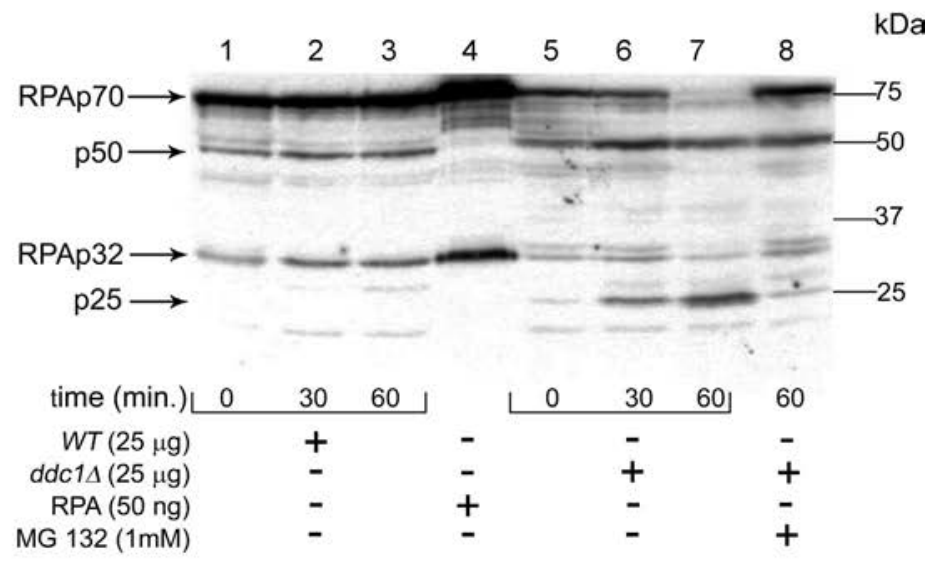

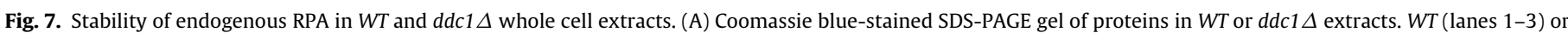

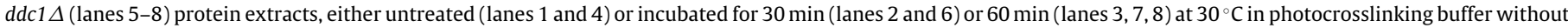

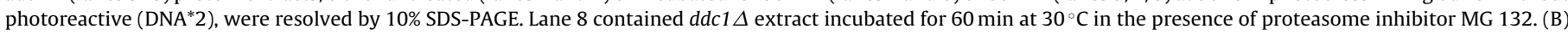
Western blot analysis of endogenous RPA in WT and $d d c 1 \Delta$ extracts using anti-RPA antibodies. Lanes were as before in (A). Lane 4 contained purified yeast RPA ( 50 ng). 
A

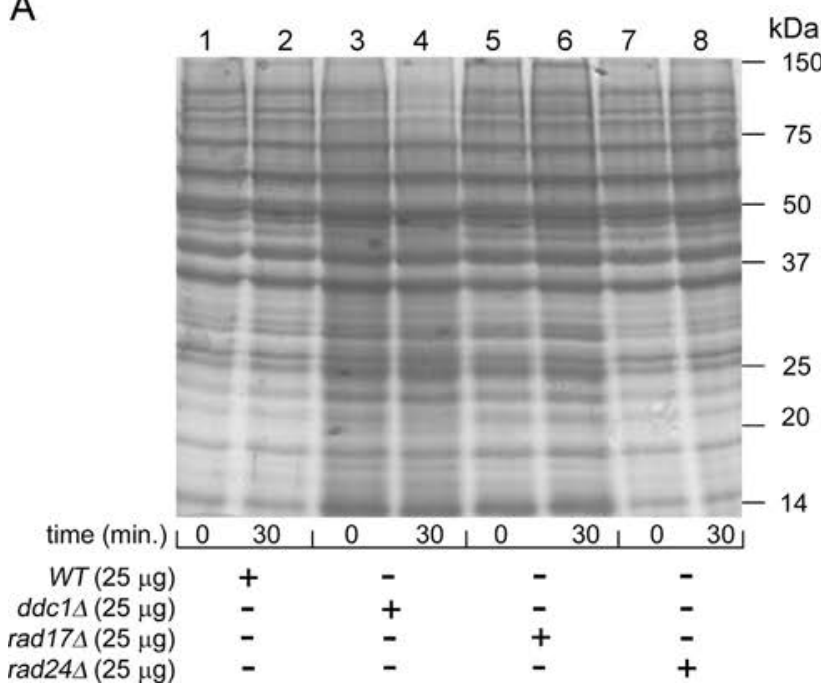

B

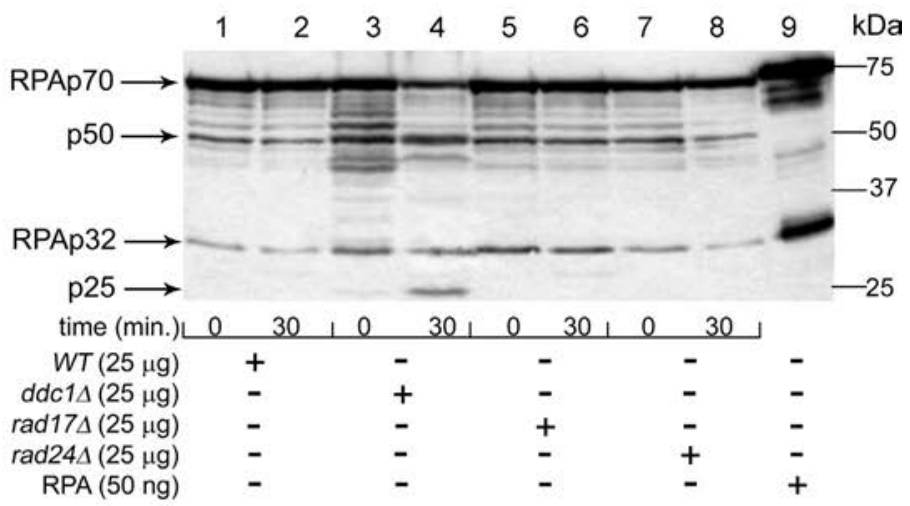

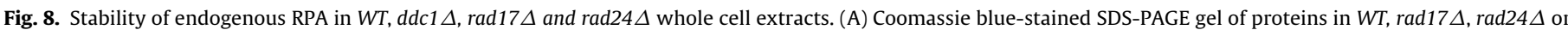

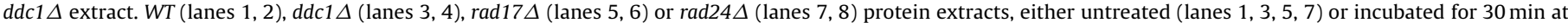

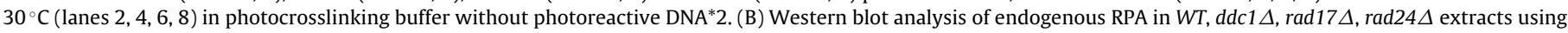
anti-RPA antibodies. Lanes were as before in (A), with the exception of lane 9 that contained purified yeast RPA (50 ng).

in the WT extract significantly reduce the proteolysis of RPAp70$\mathrm{DNA}^{*} 2$, which may point to an inhibitor of proteasome already present in the $W T$ extract (Fig. 5B). On the other hand, the addition of Gst-Ddc1 to ddc1 $\Delta$ extract has a minor effect on the cleavage of RPAp70-DNA*2 adducts (Fig. $5 \mathrm{C}$ and D). These results rather suggest an indirect role of Ddc1 in the prevention of the degradation of RPAp70 already crosslinked to DNA*2. Possibly, Ddc1 could impact the formation or the stability of an inhibitor of the proteasome in $W T$ yeast cells.

In the last part of our study, we addressed the question of the specificity of the proteolytic cleavage of yeast proteins by proteasome, in $d d c 1 \Delta$ extracts. First, we addressed the question of the proteolysis of proteins, which are not crosslinked to DNA using RPAp70 as a model. To investigate the stability of RPAp70 either free or not covalently attached to DNA in $d d c 1 \Delta$ extracts, we used Western blotting analysis with antibodies against RPA. The results show a rapid degradation of free RPAp70 in $d d c 1 \Delta$ extracts, whereas it is stable in $W T$, rad17 $\Delta$ or rad24 $\Delta$ extracts (Figs. $7 \mathrm{~B}$ and $8 \mathrm{~B}$ ). We concluded that covalent linkage to DNA is not necessary to promote RPAp70 proteolysis in $d d c 1 \Delta$ extracts. Second, we addressed the question of the rapid proteasomal degradation of three other proteins that can interact with DNA, namely: RPAp32, Gst-Ddc1 and 8-oxoguanine DNA glycosylase (Ogg1), in $d d c 1 \Delta$ extracts. The data show that RPAp32 or Gst-Ddc1 crosslinked to DNA*1 are not efficiently cleaved in ddc1 $\Delta$ extracts (Supplementary Fig. S2A-D). Therefore, crosslinking to DNA is not sufficient to trigger proteasomal degradation of a protein in $d d c 1 \Delta$ extracts. Finally, Western blot analysis shows that a DNA binding protein such as Ogg1 is stable in $d d c 1 \Delta$, like in $W T$ extracts (Supplementary Fig. S3). This last results show that all DNA binding proteins are not subject to rapid proteolysis in absence of Ddc1. Therefore, Ddc1 appears "relatively specific" preventing the proteasomal degradation of DNA binding proteins such as RPAp70 or the Topoisomerase 1 [25]. However, we do not exclude the possibility of other target proteins based on the rational that remains unclear.

Supplementary material related to this article can be found, in the online version, at http://dx.doi.org/10.1016/ j.dnarep.2014.07.002.

It should be noted that RPAp70 is present at nearly normal level in $d d c 1 \Delta$ extract, although some cleavage products are observed (Fig. 8B). Possibly, in vivo, the degradation of RPAp70 in $d d c 1 \Delta$ is reduced and/or compensated by protein de novo synthesis. Indeed, the presence of RPAp70 in ddc1 $\Delta$ extracts is in agreement with the apparently normal growth rate of cells deleted for $D D C 1$ (data not shown). Interestingly, cleavage pattern of RPAp70 covalently attached to DNA, or not (free RPA protein or DNA associated), are similar (Figs. 4A, 7B and 8B). In both cases, cleavage of RPAp70 appears rather specific with the accumulation of a major product of about $50-\mathrm{kDa}$ (p50). As a working hypothesis, we propose that proteolytic degradation of RPAp70 by proteasome would occur when RPA is loaded at ss/dsDNA junctions. In WT cells, under normal cell growth, the cleavage of RPAp70 is not detectable because of low level of DNA damage (RPA targets), and "protection" mediated by Ddc1. In $d d c 1 \Delta$ cells, under normal cell growth, cleavage of RPAp70 is moderate, although detectable, due to the low level of DNA damage and protein de novo synthesis. In WT cells exposed to DNA damaging agent, high levels of ss/ds DNA junctions are formed, massively recruiting RPA, overcoming the "protection" by Ddc1, allowing cleavage of RPAp70 and other proteins by the proteasome, resulting in cell signaling. The role of the yeast $19 \mathrm{~S}$ proteasome in the regulation of double-strand break (DSB) repair, nucleotide excision repair and base excision repair has been reported [42-45]. This study points to a novel function for Ddc1, modulating the proteolysis of DNA binding proteins by proteasome, which could be used in the course of the DNA damage response [46].

\section{Conflict of interest}

The authors declare that there are no conflicts of interest.

\section{Acknowledgements}

The work was supported by Russian Foundation for Basic Research (13-04-40197-COMFI, 14-04-00268), RAS Presidium Program "Molecular and Cell Biology" (6.4), grant for Leading Scientific Schools (420.2014.4). Centre National de la Recherche Scientifique (CNRS) and Commissariat à l'Energie Atomique (CEA). The authors would like to express thanks to Gayko N.D. (ICBFM, Laboratory of Bioorganic Chemistry of Enzymes) for purification of yeast RPA and Kassakin M.F. (ICBFM, Core Facility of Mass Spectrometric Analysis) for MALDI-TOF mass spectrum. The authors would like to express thanks to Dr. Peter M. Burgers, Xavier Veaute and Vincent Geli for 
the kind gift of purified yeast (9-1-1) complex, yeast RPA and polyclonal rabbit anti-RPA antibodies, respectively. The thank Patricia Auffret van der Kemp for her assistance in preparing yeast cell free extracts.

\section{References}

[1] R.D. Wood, T. Lindahl, Quality control by DNA repair, Science 286 (1999) 1897-1905

[2] J. Melo, D. Toczyski, A unified view of the DNA-damage checkpoint, Curr. Opin. Cell Biol. 14 (2002) 237-245.

[3] J.C. Harrison, J.E. Haber, Surviving the breakup: the DNA damage checkpoint, Annu. Rev. Genet. 40 (2006) 209-235.

[4] C.D. Putnam, E.J. Jaehnig, R.D. Kolodner, Perspectives on the DNA damage and replication checkpoint responses in Saccharomyces cerevisiae, DNA Repair 8 (2009) 974-982.

[5] K. Myung, R.D. Kolodner, Suppression of genome instability by redundant Sphase checkpoint pathways in Saccharomyces cerevisiae, Proc. Natl. Acad. Sci. U.S.A. 99 (2002) 4500-4507.

[6] Y. Shiloh, ATM and related protein kinases: safeguarding genome integrity, Nat. Rev. Cancer 3 (2003) 155-168.

[7] C.A. MacDougall, T.S. Byun, C. Van, M.C. Yee, K.A. Cimprich, The structural determinants of checkpoint activation, Genes Dev. 21 (2007) 898-903.

[8] V.M. Navadgi-Patil, P.M. Burgers, A tale of two tails: activation of DNA damage checkpoint kinase Mec1/ATR by the 9-1-1 clamp and by Dpb11/TopBP1, DNA Repair 8 (2009) 996-1003.

[9] J.A. Melo, J. Cohen, D.P. Toczyski1, Two checkpoint complexes are independently recruited to sites of DNA damage in vivo, Genes Dev. 15 (2001) 2809-2821.

[10] T. Kondo, T. Wakayama, T. Naiki, K. Matsumoto, K. Sugimoto, Recruitment of Mec1 and Ddc1 checkpoint proteins to double-strand breaks through distinct mechanisms, Science 294 (2001) 867-870.

[11] L. Zou, S.J. Elledge, Sensing DNA damage through ATRIP recognition of RPA-ssDNA complexes, Science 300 (2003) 1542-1548.

[12] C. Venclovas, M.P. Thelen, Structure-based predictions of Rad1, Rad9, Hus1 and Rad17 participation in sliding clamp and clamp-loading complexes, Nucleic Acids Res. 28 (2000) 2481-2493.

[13] T. Kondo, K. Matsumoto, K. Sugimoto, Role of a complex containing Rad17, $\mathrm{Mec} 3$, and Ddc1 in the yeast DNA damage checkpoint pathway, Mol. Cell. Biol. 19 (1999) 1136-1143.

[14] J. Majka, P.M. Burgers, Yeast Rad17/Mec3/Ddc1: a sliding clamp for the DNA damage checkpoint, Proc. Natl. Acad. Sci. U.S.A. 100 (2003) 2249-2254.

[15] V.P. Bermudez, L.A. Lindsey-Boltz, A.J. Cesare, Y. Maniwa, J.D. Griffith, J. Hurwitz, A. Sancar, Loading of the human 9-1-1 checkpoint complex onto DNA by the checkpoint clamp loader hRad17-replication factor C complex in vitro, Proc. Natl. Acad. Sci. U.S.A. 100 (2003) 1633-1638.

[16] J.J. Majka, S.K. Binz, M.S. Wold, P.M. Burgers, Replication protein A directs loading of the DNA damage checkpoint clamp to 5'-DNA junctions, J. Biol. Chem. 281 (2006) 27855-27861.

[17] J. Majka, A. Niedziela-Majka, P.M. Burgers, The checkpoint clamp activates Mec1 kinase during initiation of the DNA damage checkpoint, Mol. Cell 24 (2006) 891-901.

[18] C.Y. Bonilla, J.A. Melo, D.P. Toczyski, Colocalization of sensors is sufficient to activate the DNA damage checkpoint in the absence of damage, Mol. Cell 30 (2008) 267-276.

[19] R. Parrilla-Castellar, S.J. Arlander, L. Karnitz, Dial 9-1-1 for DNA damage: the Rad9-Hus1-Rad1 (9-1-1) clamp complex, DNA Repair 3 (2004) 1009-1014.

[20] F. Marini, T. Nardo, M. Giannattasio, M. Minuzzo, M. Stefanini, P. Plevani, M. Muzi Falconi, DNA nucleotide excision repair-dependent signaling to checkpoint activation, Proc. Natl. Acad. Sci. U.S.A. 103 (2006) 17325-17330.

[21] V.M. Navadgi-Patil, P.M. Burgers, The unstructured C-terminal tail of the 9-1-1 clamp subunit Ddc1 activates Mec1/ATR via two distinct mechanisms, Mol. Cell 36 (2009) 743-753.

[22] L. Zou, D. Liu, S.J. Elledge, Replication protein A-mediated recruitment and activation of Rad17 complexes, Proc. Natl. Acad. Sci. U.S.A. 100 (2003) 13827-13832.

[23] V. Ellison, B. Stillman, Biochemical characterization of DNA damage checkpoint complexes: clamp loader and clamp complexes with specificity for $5^{\prime}$ recessed DNA, PLoS Biol. 1 (2003) 231-243.
[24] A. Ciccia, S.J. Elledge, The DNA damage response: making it safe to play with knives, Mol. Cell 40 (2010) 179-204

[25] M.V. Sukhanova, C. D'Herin, P.A. van der Kemp, V.V. Koval, S. Boiteux, O.I. Lavrik, Ddc1 checkpoint protein and DNA polymerase $\varepsilon$ interact with nick-containing DNA repair intermediate in cell free extracts of Saccharomyces cerevisiae, DNA Repair 10 (2011) 815-825.

[26] I.A. Drachkova, I.O. Petruseva, I.V. Safronov, A.L. Zakharenko, G.V. Shishkin, O.I. Lavrik, S.N. Khodyreva, Reagents for modification of protein-nucleic acids complexes. II. Site-specific photomodification of DNA-polymerase beta complexes with primers elongated by the dCTP exo-N-substituted arylazido derivatives, Bioorg. Khim. (Mosc.) 27 (2001) 197-204.

[27] S.K. Binz, A.M. Dickson, S.J. Haring, M.S. Wold, Functional assays for replication protein A (RPA), Methods Enzymol. 409 (2006) 11-38.

[28] P.M. Girard, N. Guibourt, S. Boiteux, The Ogg1 protein of Saccharomyces cerevisiae: a 7,8-dihydro-8-oxoguanine DNA glycosylase/AP lyase whose lysine 241 is a critical residue for catalytic activity, Nucleic Acids Res. 25 (1997) 3204-3211.

[29] M.S. Longtine, A. McKenzie 3rd, D.J. Demarini, N.G. Shah, A. Wach, A. Brachat, P. Philippsen, J.R. Pringle, Additional modules for versatile and economical PCRbased gene deletion and modification in Saccharomyces cerevisiae, Yeast 10 (1998) 953-961.

[30] A. Baudin, O. Ozier-Kalogeropoulos, A. Denouel, F. Lacroute, C. Cullin, A simple and efficient method for direct gene deletion in Saccharomyces cerevisiae, Nucleic Acids Res. 21 (1993) 3329-3330.

[31] U.K. Laemmli, Cleavage of structural proteins during the assembly of the head of bacteriophage T4, Nature 227 (1970) 680-685.

[32] E.S. Ilina, O.I. Lavrik, S.N. Khodyreva, Ku antigen interacts with abasic sites, Biochim. Biophys. Acta 1784 (2008) 1777-1785.

[33] A. Shevchenko, H. Tomas, J. Havlis, J.V. Olsen, M. Mann, In-gel digestion for mass spectrometric characterization of proteins and proteomes, Nat. Protocols 1 (2006) 2856-2860.

[34] C. Borchers, J.F. Peter, M.C. Hall, T.A. Kunkel, K.B. Tomer, Identification of in gel digested proteins by complementary peptide-mass fingerprinting and tandem mass spectrometry data obtained on an electrospray ionization quadrupole time-of flight mass spectrometer, Anal. Chem. 72 (2000) $1163-1168$.

[35] M.S. Wold, Replication protein A: a heterotrimeric, single-stranded DNAbinding protein required for eukaryotic DNA metabolism, Annu. Rev. Biochem. 66 (1997) 61-92.

[36] D.M. Kolpashchikov, S.N. Khodyreva, D.Y. Khlimankov, M.S. Wold, A. Favre, O.I. Lavrik, Polarity of human replication protein A binding to DNA, Nucleic Acids Res. 29 (2001) 373-379.

[37] W.L. de Laat, E. Appeldoorn, K. Sugasawa, E. Weterings, N.G.J. Jaspers, J.H.J. Hoeijmakers, DNA-binding polarity of human replication protein A positions nucleases in nucleotide excision repair, Genes Dev. 12 (1998) 2598-2609.

[38] O.I. Lavrik, D.M. Kolpashchikov, K. Weisshart, H.P. Nasheuer, S.N. Khodyreva, A. Favre, RPA subunit arrangement near the 3 '-end of the primer is modulated by the length of the template strand and cooperative protein interactions, Nucleic Acids Res. 21 (1999) 4235-4240.

[39] A.M. Carr, DNA structure dependent checkpoints as regulators of DNA repair 1 (2002) 983-994.

[40] J.W. Harper, S.J. Elledge, The DNA damage response: ten years after, Mol. Cell 28 (2007) 739-745.

[41] S.P. Jackson, J. Bartek, The DNA-damage response in human biology and disease, Nature 461 (2009) 1071-1078.

[42] N.J. Krogan, M.H. Lam, J. Fillingham, M.C. Keogh, M. Gebbia, J. Li, N. Datta, G. Cagney, S. Buratowski, A. Emili, J.F. Greenblatt, Proteasome involvement in the repair of DNA double-strand breaks, Mol. Cell 16 (2004) 1027-1034.

[43] T.G. Gillette, W. Huang, S.J. Russell, S.H. Reed, S.A. Johnston, E.C. Friedberg, The $19 S$ complex of the proteasome regulates nucleotide excision repair in yeast. Genes Dev. 15 (2001) 1528-1539.

[44] N.P. Dantuma, C. Heinen, D. Hoogstraten, The ubiquitin receptor Rad23: at the crossroads of nucleotide excision repair and proteasomal degradation, DNA Repair 8 (2009) 449-460.

[45] D.S. Karpov, D.S. Spasskaya, V.V. Tutyaeva, A.S. Mironov, V.L. Karpov, Proteasome inhibition enhances resistance to DNA damage via upregulation of Rpn4-dependent DNA repair genes, FEBS Lett. 587 (2013) 3108-3114.

[46] I. Kouranti, A. Peyroche, Protein degradation in DNA damage response, Semin. Cell Dev. Biol. 23 (2012) 538-545. 